\title{
COMPUTATIONAL ASSESSMENT OF FOUR CYLINDERS SI ENGINEWORKING ON PETROL OR DUAL FUEL MODE(LPG-PETROL)
}

\author{
Ahmed Mohsin Gatea ${ }^{1}$ \\ ahmed.m.gatea@gmail.com
}

\author{
Karima Esmail Amori \\ drkarimaa63@gmail.com
}

\author{
Hammid Unis Salih ${ }^{3}$ \\ deputy.gasaffairs@yahoo.com
}

1,2 University of Baghdad- College of engineering-Department of Mechanical engineering

${ }^{3}$ Ministry of Oil

\section{ABSTRACT}

Liquefied petroleum gas LPG is a good alternative to gasoline fuel. It has emerged as a solution to the deteriorating urban air quality problem especially in an oil country like Iraq. Computational model is used for parametric study of spark ignition engine works on Iraqi fuel (gasoline or LPG). Transient one dimensional continuity, momentum and energy equations are solved by two - step Lax wender off (Ritchmyer) approach to evaluate brake specific fuel consumption BSFC, brake power, brake thermal efficiency, volumetric efficiency, air fuel ratio, in cylinder pressure and exhaust gas temperature. Results revealed that LPG fuel improves BSFC by $3.11 \%$ as a maximum compare to gasoline for $10 \mathrm{~kW}$ brake power and 9.9:1 compression ratio. The maximum cylinder pressures predicted for LPG are lower than that for gasoline fuel. The volumetric efficiency was $76.8 \%$ for engine works with, LPG at compression ratio 9.9:1. While that for gasoline was $85.9 \%$. The equivalence ratio is higher for gasoline than that for LPG, since the first required higher air-fuel ratio for combustion. The reported maximum exhaust gas temperature for LPG is $706^{\circ} \mathrm{C}$, while that for gasoline is $741.4^{\circ} \mathrm{C}$.

Keywords: SI engine, Gasoline, Liquefied Petroleum Gas (LPG), Performance, Exhaust gas temperature

$$
\begin{aligned}
& \text { تقييم حسابي لمحرك احتراق داخلي ذو أربع أسطوانات يعمل بوقود (بنزين)او ثنائي }
\end{aligned}
$$

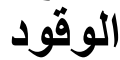

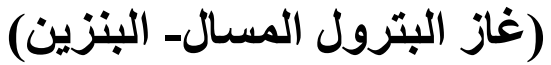

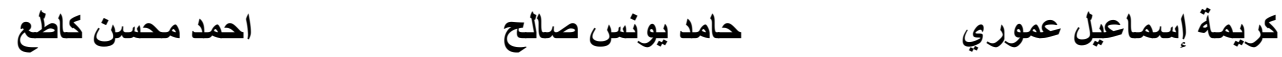

يعتبر غاز البترول المسال LPG بديلا جيدا للكازولين. اظهر هذا الوقود حلا لمشكلة تردي نوعية هواء المناطق الحضرية

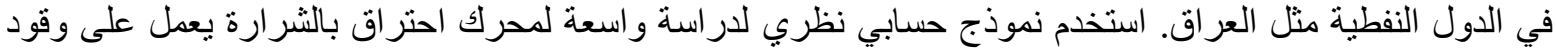

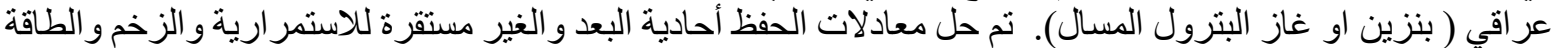

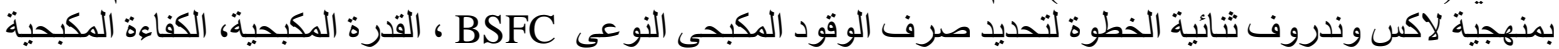

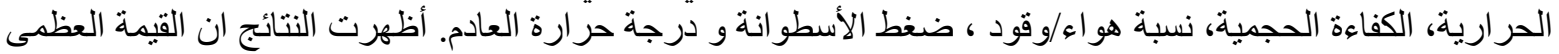

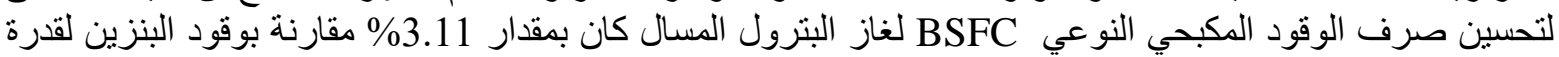

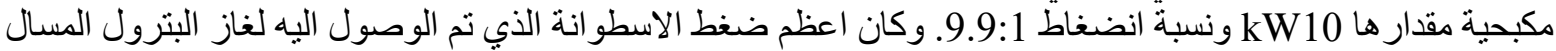
اقل مما هو عليه لوقود البنزين. ان الكفاءة الحجمية للمحرك كانت أنط 


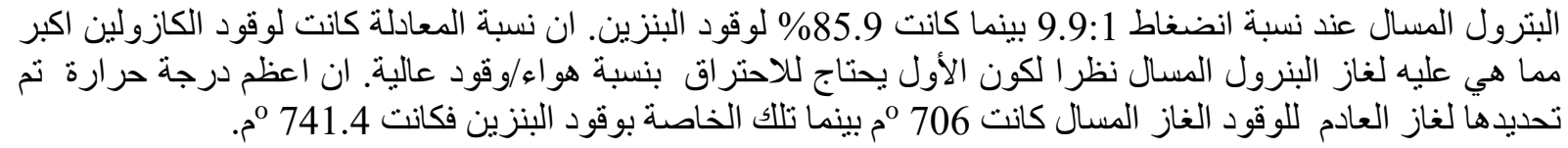

NOMENCLTURE

\section{Latin Symbols}

BSFC

BTDC

$b$

bmep

CNG

$\mathrm{D}$

$\mathrm{dV}$

DI

DOHC

e

$\mathrm{F}$

$f$

FA

$\mathrm{FA}_{\mathrm{s}}$

fmep

$\mathrm{h}$

$\mathrm{H} / \mathrm{C}$

imep

LPG

$\dot{\mathrm{m}}_{\mathrm{ia}}$

$\dot{m}_{\mathrm{f}}$

$\mathrm{N}$

$\mathrm{n}_{\mathrm{r}}$

$P$

$\mathrm{P}_{\mathrm{e}}$

q

QLHV

$\mathrm{R}$

$s$

SOHC

T

$\mathrm{t}$

$V_{d}$

$\mathrm{W}_{\mathrm{c}}$

$\mathrm{y}$

Z

\section{Greek letters}

$\begin{array}{ll} & \eta_{\text {th }} \\ & \eta_{v} \\ \lambda & \\ \rho & \end{array}$

\section{Description}

brake specific fuel consumption $(\mathrm{kg} / \mathrm{kWh})$

before top dead center

cylinder bore ( $\mathrm{mm})$

brake mean effective pressure (bar)

compressed natural gas

diameter of the duct ( $\mathrm{mm}$ )

Volume $\left(\mathrm{mm}^{3}\right)$

direct injection

double overhead camshaft

internal energy $(\mathrm{kJ})$

force $(\mathrm{N})$

pipe wall friction coefficient (mm.sec)

fuel /air ratio

stoichiometric fuel /air ratio

friction mean effective pressure

Enthalpy (kJ)

hydrogen to carbon ratio

indicated mean effective pressure (bar)

liquefied petroleum gas

inlet air mass flow rate $(\mathrm{kg} / \mathrm{h})$

fuel mass flow rate $(\mathrm{kg} / \mathrm{h})$

engine rotational speed (rpm)

revolution per cycle and is taken as 2 for four stroke engines

pressure (bar)

brake power $(\mathrm{kW})$

rate of heat transfer per unit mass $(\mathrm{W} / \mathrm{kg})$

lower heating calorific value of fuel $(\mathrm{kJ} / \mathrm{kg})$.

air constant $(\mathrm{kJ} / \mathrm{K} . \mathrm{mol})$

piston stroke $(\mathrm{mm})$

single overhead camshaft

temperature $\left(\mathrm{k}\right.$ or $\left.{ }^{\circ} \mathrm{C}\right)$

time (sec)

displacement volume $\left(\mathrm{mm}^{3}\right)$

net indicated work per cycle $(\mathrm{kJ})$.

distance $(\mathrm{mm})$

the cylinder number

brake thermal efficiency

volumetric efficiency

equivalence ratio

ratio of actual to stoichiometric air/fuel ratio

density $\left(\mathrm{kg} / \mathrm{m}^{3}\right)$ 


$\begin{array}{ll}\text { Subscripts } & \text { Description } \\ B D C & \text { bottom dead center } \\ \text { ia } & \text { inlet air } \\ \text { o } & \text { Stagnation } \\ T D C & \text { top dead center }\end{array}$

\section{INTRODUCTION}

Most internal combustion engines are used in automobile applications such as cars, aircrafts, boats and power generation etc. Environmental concerns and depletion in petroleum resources have forced researchers to concentrate on finding alternatives to conventional petroleum fuels. Liquefied Petroleum Gas LPG has efficient combustion characteristics and low gases emission, so it is considered as an alternative fuel for gasoline in spark-ignition (SI) engines. Higher octane number for LPG enables higher engine compression ratio, and results higher thermal efficiency Snelgrove (1996).LPG has high octane rating $110^{+}$that allows compression ratios to be high up to $15: 1$, (the range of 8:1 to 9.5:1 for gasoline engines). Also, since LPG enters an engine's combustion chambers as a vapor, it does not strip oil from cylinder walls or dilute the oil when the engine is cold. Cycle simulation studies had great interest Heywood (1988), Bayraktar (1997). Recently, much researches are conducted on alternative fuels due to increasing demand to lower fuel consumption and exhaust emissions. These improve the awareness of the effective use of present reserves and slowly switches over to the alternative friendly environment fuels, Nirendra(2008), Lata et al. (2011) and Krishna et al. (2011). One of the solutions to accomplish this target is the use of gaseous fuels in SI engine. The use of alternative gaseous fuels e.g. liquefied natural gas LNG, liquefied petroleum gas (LPG), etc can be adopted in SI engine for automobiles, power plants, ships etc. SI engines are a premixed air-fuel mixture followed by compression before a spark ignites the mixture and burned. Octane rating of a fuel indicates how slowly the fuel will burn and how fuel will resist pre-ignition before the spark plug fires. This helps to have a longer service life and reduced maintenance costs of engine. Ozcan and Yamin (2008), simulated the effect of variable the stroke length (compression ratio) of LPG fueled engine. The results obtained were compared with the experimental results of both constant and variable stroke lengths. It was concluded that brake power registered an increase of about 7-54\% at low speed and $7-57 \%$ at high speed for all investigated stroke length. BSFC reported a reduction of about $6 \%$ to an increase of about $3 \%$ at low speed and from a reduction of about $6 \%$ to an increase of about $8 \%$ at high speeds. The concentration of pollutants is increased from $0.65 \%$ to $2 \%$ at low speed while larger stroke lengths resulted a reduction of pollutant level of about $1.5 \%$ at higher speed while at lower stroke length an increase of about $2 \%$ is indicated. Mustafa and Briggs (2009), tested LPG-gasoline engine with different LPG volume content of $(5 \%, 10 \%$ and $20 \%)$ at constant engine speed $(4000 \mathrm{rpm})$ but at varying values of air-fuel ratio. Power output is decrease by $20 \%$ and $41 \%$, for $5 \%$ and $20 \%$ LPG-gasoline blended as compared to $100 \%$ gasoline. Brake specific fuel consumption (BSFC) for LPG-gasoline blends is slightly lower than that of $100 \%$ gasoline, the difference in the minimum value of BSFC was found to be $47 \%$ and $58 \%$ for $5 \%$ and $20 \%$ LPG-gasoline blended respectively. It was reported that LPG addition does not lead to a significant improvement in brake thermal efficiency. The concentration levels of $\mathrm{CO}, \mathrm{CO}_{2}$, unburnt $\mathrm{HC}$ and $\mathrm{NO}_{\mathrm{x}}$ for $\mathrm{LPG}$ fueled engine were found lower than the gasoline fueled engine. Pourkhesalian et al. (2009) investigated the performance of a four stroke, four cylinders SI engine fueled with different alternative fuels. when the engine is fed with gaseous fuels results a decrease in volumetric efficiency 
and power output, since gaseous fuels have low density as compared to gasoline. Brake specific fuel consumption of engine, operating on, propane is lower than that of gasoline. Arslan et al. (2010) tested LPG fueled four cylinders SI engine to estimate its performance and exhaust emission under cold climatic conditions in Turkey. SFC increases with the increasing of engine speed for both fuel types with higher values for LPG by $22-32 \%$. Despite this fact, the cost of LPG consumption per km is less. Concentration of CO was found to be reduced with increasing of engine speed, but for LPG this reduction was higher and it was accounted to be $91.9 \%$. A decrease in HC emission can be achieved as a percentage ranging between 10.1 and 29.7, when there is a mixer with no load on the engine. An increase in $\mathrm{HC}$ emissions at $1,000 \mathrm{rpm}$ of $1.5 \%$ and $2.9 \%$ is reported for the cases of off-load and onload, respectively. Concentration of $\mathrm{CO}_{2}$ was decreased at off-load in a percentage range between 13.4 and 16.7. This value ranges 13.4-22.7, for full load case. Shankar and Mohanan (2011), studied the effect of variation in ignition timing on the performance of four cylinders multipoint port fuel injection gasoline engine which is retrofitted to run with LPG injection. Since the ignition temperature is high for LPG therefore combustion duration is longer and this decreases average burning rate. So, engine consumes more fuel and thus decreases in brake thermal efficiency. But at higher engine speeds, the flame propagation speed of LPG is increased which lowers the time duration for each cycle and thus demands more rate of combustion and hence efficiency increases. $\mathrm{CO}$ and $\mathrm{HC}$ emission are reduced drastically for LPG at all the throttle positions while $\mathrm{NO}_{\mathrm{x}}$ emission were found to be increased for LPG and was almost doubled at $4500 \mathrm{rpm}$. At $6^{\circ} \mathrm{BTDC}, \mathrm{CO}$ and $\mathrm{HC}$ emissions were found to be lower than that at $3^{\circ}$ and $4^{\circ}$ BTDC due to complete combustion resulted from high propagation speed of LPG. Concentration of $\mathrm{NO}_{\mathrm{x}}$ was $1400 \mathrm{PPM}$ at $6^{\circ} \mathrm{BTDC}$ and 500 $\mathrm{PPM}$ at $3^{\circ} \mathrm{BTDC}$ due to low combustion temperature because of incomplete combustion at this angle. Gumus (2011) investigated the effect of variation in volumetric efficiency and SI engine performance (for Renault Clio 1.4i RTA vehicle and 4 cylinder) at different LPG usage levels with gasoline $(25 \%, 50 \%, 75 \%$ and 100\%) on an engine equipped with electronically controlled multipoint sequential gas injection system. The experiments were carried out at constant engine speed of (3800 rpm) and at different loads conditions $(5 \%, 30 \%$, $60 \%$ and $90 \%$ ). The volumetric efficiency is decreased considerably with the use of $25 \%$ LPG. Best results of exhaust emissions were obtained for 100\% LPG.Pundkar et al. (2012), presented the effect of engine torque, power and specific fuel economy on engine efficiency. As the gaseous fuel requires 4 to 15 percent of more intake passage volume than liquid fuels which reduces the volumetric efficiency and hence maximum power output will also be reduced (by 4\%). Erkus et.al. (2013), investigated the effect of electronically controlled gas phase manifold LPG injection system on the SI engine performance fueled with LPG at 2000$4000 \mathrm{rpm}$ and fixed throttle position of $25 \%$ as well as $45 \%$ of full opening. During tests, the excess air coefficient was maintained in the range of 0.95 to 1.05 . At $25 \%$ throttle position with the LPG injection system, the maximum improvement in the brake power achieved were $99.52 \%$ and $84.84 \%$ compared to gasoline and LPG carburetion, at $3500 \mathrm{rpm}$. While at 50\% throttle position, brake power of the engine was always higher with LPG injection system than with the carburetion systems at $3000 \mathrm{rpm}$. Volumetric efficiency is improved with LPG injection system as compared to carburetion systems at both $25 \%$ and $50 \%$ throttle positions. Brake-specific fuel consumption (BSFC) was lower for LPG injection system at both the throttle positions except at $2500 \mathrm{rpm}$ for $25 \%$ throttle position. Although, experimental investigation provides actual results for internal combustion engine operation, but it is more expensive and requires more time than computational methods. The aim of this work is to establish specifications of four cylinders four stroke engine fueled with LPG to reduce emission gases compared with gasoline fuel. Contribution of this work is that simulation 
program is used for a four-cylinder SI engine to perform variation of engine parameters. Study engine efficiency with the aid of superior physical or chemical properties software (lower calorific vale, density and $\mathrm{H} / \mathrm{C}$ ratio ... etc) of alternative fuels compared to those of conventional fuels under different compression ratios $(8: 1,9.9: 1,10.25$ and 15). This work presents a first try to investigate the performance of 4-cylinder 4-stroke SI engine works on Iraqi LPG fuel as an alternative engine fuel.

\section{MATHMETICAL AND NUMERICAL MODEL}

Governing equations of gas flow in pipes, cylinders, heat transfer and combustion modeling, ports, valves, charge cooling and engine dynamics are individually described. To build the computational model, of the multi cylinder engine, and calculate the cycle performance data, the brake power $\left(\mathrm{P}_{\mathrm{e}}\right)$, the brake thermal efficiency $\left(\eta_{\mathrm{bth}}\right)$ and the brake specific consumption of fuel (BSFC). The following steps were followed:-

1. Defining steady-state test condition data.

2. Engine and fuel system building.

\section{Steady State Test Condition Data}

The full load performance steady-state operating conditions simulation of an engine model consists of the intake manifold system, valve train, displacement volume and the exhaust manifold system. The development of an in-line four cylinder and four stroke indirect injection, liquid cooling SI engine model in the simulation software required the following engine and manifold specifications. The input data required for engine simulation can be presented as (see table (3.1.a, b, c and d):

a. The initial conditions $\left(\mathrm{Patm}=1 \mathrm{bar}\right.$, Tatm $\left.=25^{\circ} \mathrm{C}\right)$.

b. The engine bore.

c. Stroke dimension.

d. Number of cylinders.

e. Compression ratio.

f. Valve timing data.

g. Intake and exhaust manifold dimensions.

$\mathrm{h}$. Engine model the requirements can be defined as the engine speed (rpm) which was from $1000 \mathrm{rpm}$ to $3500 \mathrm{rpm}$, with an increment of $500 \mathrm{rpm}$

i. The Air / fuel ratio.

\section{THE ENGINE MODEL}

\section{Building Of The Engine}

Building simulation model (cylinder, inlet and exhaust manifold ports and valves) is done only for one cylinder and the other cylinders shared the same specifications, figure (1) shows the complete one-cylinder model. After that it was copied with all the configuration four times to produce a four cylinders engine with a consideration of setting the fire order to (1-3-4-2). Figures (2 and 3) show the real model of the petrol engine. The next part is adding the inlet and exhaust manifold ports and valves. Which inched valve timing. The specifications of the engine are given in table (1).

\section{Steps of Les Engine Model}

After the schematically steps of engine model built in LES as shown in figure (4). Every step, the program checks the validity of the built engine model or inserted data and specifications. Finally, when the operating conditions are determined to be true, then the simulation is run at the specified engine speed to achieve the demanded engine loading with the inserted fuel injection rate.

\section{GOVERINING EQUATIONS}

One-dimensional transient model of pipe gas dynamics are applied for the gas flow in pipes. At each time step (crank angle), conservation differential equations for mass, momentum and energy are solved for calculating the conditions within pipe elements. The 
flow of a compressible fluid through an infinitesimal section of pipe is shown in Figure (5). When the area variation is small, the fluid properties can be taken uniform across any crosssection and can be considered as a function of $\mathrm{x}$ and time only. Therefore, the flow can be assumed as quasi-one-dimensional (Winterbone and Pearson 1999 and Winterbone and Pearson2000). The related properties are pressure, density, velocity of flow and crosssectional area.

The governing equations (continuity, momentum and energy equations in order) for the transient one-dimensional flow of a compressible fluid in a pipe with area variation are (Winterbone and Pearson 2000):

$\frac{\partial(\mathrm{pF})}{\partial \mathrm{t}}+\frac{\partial(\mathrm{puF})}{\partial \mathrm{x}}=0$

$\frac{\partial(\mathrm{puF})}{\partial \mathrm{t}}+\frac{\partial\left(\mathrm{pu}^{2}+\mathrm{p}\right) \mathrm{F}}{\partial \mathrm{x}}-\mathrm{p} \frac{d F}{d x}+\frac{1}{2} \rho \mathrm{u}^{2} f \pi D=0$

$\frac{\partial\left(\mathrm{pe}_{\mathrm{0}} \mathrm{F}\right)}{\partial \mathrm{t}}+\frac{\partial\left(\mathrm{puh}_{\mathrm{o}} \mathrm{F}\right)}{\partial \mathrm{x}}-\mathrm{q} \rho \mathrm{F}=0$

The equations can also be presented in vector form as:

$\frac{\partial \mathrm{W}}{\partial \mathrm{t}}+\frac{\partial \mathrm{F}(\mathrm{W})}{\partial \mathrm{x}}+\mathrm{C}=0$

where

$$
\begin{array}{r}
\mathrm{W}=\left(\begin{array}{l}
\rho \mathrm{F} \\
\rho \mathrm{Fu} \\
\rho \mathrm{e}_{0} \mathrm{~F}
\end{array}\right) \\
\mathrm{F}(\mathrm{W})=\left(\begin{array}{l}
\rho \mathrm{uF}^{2} \\
\left({\rho \mathrm{u}^{2}}+\mathrm{p}\right) \mathrm{F} \\
\mathrm{uuh}_{0} \mathrm{~F}
\end{array}\right) \\
\mathbf{C}=\left(\begin{array}{l}
0 \\
-\mathrm{p} \frac{d F}{d x} \\
0
\end{array}\right)+\left(\begin{array}{l}
0 \\
\rho \mathrm{Gf} \\
-\mathrm{q} \rho \mathrm{F}
\end{array}\right)
\end{array}
$$

The two-step Lax-Wendroff (Richtmyer) is used to solve the governing equations above. This numerical method is a space- centered scheme based on the computational stencil shown in Figure (6) (Winterbone and Pearson 2000). This scheme can be modified to include the source terms and can be expressed by explicit forward finite difference scheme at node $(i+1)$ such that

$$
W_{i+1 / 2}^{n+1 / 2}=\frac{1}{2}\left(W_{i+1}^{n}+W_{i}^{n}\right)-\frac{\Delta t}{2 \Delta x}\left(F_{i+1}^{n}-F_{i}^{n}\right)-\frac{\Delta t}{4}\left(C_{i+1}^{n}+C_{i}^{n}\right)
$$

Where the super script $n+1$ refers to the new value at time $\mathrm{t}=\mathrm{t}+\frac{1}{2} \Delta t$. While $\mathrm{n}$ refers to the current value.

Explicit forward finite difference scheme is adopted at (i-1) such that:

$$
W_{i-1 / 2}^{n+1 / 2}=\frac{1}{2}\left(W_{i}^{n}+W_{i-1}^{n}\right)-\frac{\Delta t}{2 \Delta x}\left(F_{i}^{n}-F_{i-1}^{n}\right)-\frac{\Delta t}{4}\left(C_{i}^{n}+C_{i-1}^{n}\right)
$$

Implicit forward finite difference scheme is adopted at (i) such that: 
$W_{i}^{n+1}=W_{i}^{n}-\frac{\Delta t}{\Delta x}\left(F_{i+1 / 2}^{n+1 / 2}-F_{i-1 / 2}^{n+1 / 2}\right)-\frac{\Delta t}{2}\left(C_{i+1 / 2}^{n+1 / 2}-C_{i-1 / 2}^{n+1 / 2}\right)$

Calculations of the engine performance parameters

The calculated performance parameters includes (Heywood 1988) and (Pearson et al 2002):

The brake mean effective pressure (bmep) of the SI engine is evaluated as:

bmep $=$ imepcycle - fmep

where:

fmep is friction mean effective pressure (bar).

imepcycleis indicated mean effective pressure (bar). It is calculated as:

imepcycle $=\frac{W_{c}}{V_{d}}$

$W_{\mathrm{c}}$ is defined as:

$\mathrm{W}_{\mathrm{c}}=\int \mathrm{p} \mathrm{dV}$

The displacement volume $\left(\mathbf{V}_{\mathbf{d}}\right)$ is equal to the volume of part of the cylinder envelope between top dead center (TDC) and bottom dead center (BDC) shown in figure (7). This volume can be calculated by:

$V_{\mathrm{d}}=\frac{\pi}{4} b^{2} s$

The brake power, $\mathrm{P}_{\mathrm{e}}(\mathrm{kW})$, and torque $\tau_{e}$ N.m, are evaluated as:

$\mathrm{P}_{\mathrm{e}}=\left(\frac{b \operatorname{bmep} \mathrm{V}_{\mathrm{d}} N Z}{n_{r} 60}\right)$

$\tau_{e}=\left(\frac{10^{\mathrm{a}} \mathrm{p}_{e}}{\omega}\right)$

Angular speed of the engine, $\omega(\mathrm{rad} / \mathrm{s})$, in equation (17) is defined as:

$\omega=2 \pi N / 60$

The brake specific fuel consumption, BSFC $(\mathrm{g} / \mathrm{kWh})$, is calculated with the following formula below:

$\mathrm{BSFC}=\frac{\dot{m}_{\mathrm{f}}}{\mathrm{P}_{\mathrm{f}}}$

The brake thermal efficiency of the system, $\eta_{\text {th }}$, can be calculated as:

$\eta_{\text {th }}=\frac{3600 P_{e}}{m_{\mathrm{F}^{*}} Q_{L H V}}$

Finally, volumetric efficiency is defined by:

$\eta_{v}=\frac{2 \mathrm{mia}_{\mathrm{Ia}}^{\circ} 10^{\mathrm{a}}}{60 \mathrm{P}_{\mathrm{ia}} \mathrm{v}_{\mathrm{d}} \mathrm{N}}$

Inlet air density is calculated as:

$\rho_{\text {ia }}=\frac{P_{\text {ia }} 10^{\mathrm{g}}}{R \mathrm{P}_{\mathrm{ia}}}$

where:

$\mathrm{R}$ is air constant $(287 \mathrm{~kJ} / \mathrm{K} . \mathrm{mol})$.

\section{RESULTS AND DISSECTION \\ Engine Performance}

Brake Specific Fuel Consumption

Figure (8) shows the variation of BSFC with engine speed. As the engine speed increases, BSFC is decreased gradually to its minimum value at engine speed of $3000 \mathrm{rpm}$, then increases as the speed was increased to $3500 \mathrm{rpm}$. The maximum percentage deviation of BSFC for gasoline fuel compared to LPG fuel is $3,3.11 \%, 3.51 \%$ and5.53\% for compression ratio equals 8:1,9.9:1,10.25:1 and 15:1 respectively for gasoline compared with LPG fuels since the later needs higher combustion chamber size i.e. higher temperature and pressure. Since the BSFC is a measure of the "fuel economy", lower BSFC should be the ultimate target in all engine designs. Result show that adding LPG system to the SI engine was 
beneficial towards improving BSFC. It is also evident that BSFC deteriorates as the engine speed approaches $3500 \mathrm{rpm}$, and this was attributed to the increase power required to overcome the frictional power. Since frictional power loss is proportional with engine speed, extra fuel is required to ensure sustainable engine operation which explains the increase in BSFC during the window of operation from 3000 to $3500 \mathrm{rpm}$.

\section{Brake power}

Peaks of brake power was indicated at engine speed of $3500 \mathrm{rpm}$ for as illustrated in Figure (9). Brake power increases rapidly with increasing of engine speed for each compression ratios 8:1, 9.9:1, 10.25:1 and 15:1. Maximum percentage increase of brake power for gasoline fuel compared to LPG fuel is $17.6 \%, 11.51 \%, 9.35 \%, 6.4 \%$ and $5.35 \%$ at engine speeds 1500, 2000, 2500, 3000 and $3500 \mathrm{rpm}$ respectively for compression ratio equal 8:1.For compression ratio $9.9: 1$ it is $16.7 \%, 11.1 \%, 9.1 \%, 6.25 \%$ and $5.26 \%$ at engine speeds $1500,2000,2500,3000$ and $3500 \mathrm{rpm}$ respectively for compression ratio equal 9.9:1. For compression ratio $10.25: 1$ it is $15.4 \%, 8.5 \%, 7.8 \%, 5.9 \%$ and $5.3 \%$. While for compression ratio $15: 1$ it is $13.55 \%, 7.9 \%, 7.1 \%, 5.6 \%$ and $5.13 \%$. Further, for a given engine speed, the engine brake power increases as compression ratio increases, since it is function of torque and speed. The reduction in the brake power varies between $5 \%$ to $16 \%$ for LPG compared to gasoline fuel. Due to the displacement of the fresh charge at the chamber during the intake stroke, which resulted in a decrease of engine volumetric efficiency.

\section{Brake thermal efficiency}

The peak value of brake thermal efficiency is indicated at $3000 \mathrm{rpm}$ as presented in figure (10). The range of brake thermal efficiency varies from $24.1 \%$ to $27.3 \%$ for gasoline and LPG respectively at compression ratio equals to $8: 1$. It varies from $25.1 \%$ to $30.3 \%$ for gasoline and LPG at compression ratio equals to $9.9: 1$. It varies from $25.9 \%$ to $31.4 \%$ for gasoline and LPG at compression ratio equals to $10.25: 1$. While, it varies from $26.4 \%$ to $32.2 \%$ for gasoline and LPG at compression ratio equals to $15: 1$. The maximum percentage deviation of peak brake thermal efficiency for gasoline fuel compared with LPG fuel at $3000 \mathrm{rpm}$ for compression ratio 8:1, 9.9:1, 10.25:1 and $15: 1$ are $3.84,4.2 \%, 4.7 \%$ and $5.14 \%$ respectively. LPG addition has inconsiderable improvement in terms of brake thermal efficiency due to the properties of gasoline and LPG. The heat generated in engine will be increased for LPG compared to gasoline due to the higher heating value of LPG $(45.25 \mathrm{MJ} / \mathrm{kg})$ compared to gasoline $(43.96 \mathrm{MJ} / \mathrm{kg})$. Thus, at a given engine operational speed, the amount of heat released will be greater for LPG fuel leads to higher engine brake thermal efficiency. Higher $\mathrm{H} / \mathrm{C}$ ratio for LPG compared to gasoline also ensures adequate oxygen molecule for complete carbon combustion for useful thermal conversion which improves the thermal efficiency of the engine. Higher rate of fuel utilization and higher air to fuel ratio greatly increases the combustion rate of the engine since more air and fuel is introduced to the system. At engine speeds higher than $3000 \mathrm{rpm}$, the thermal efficiency starts to decrease slightly due to the effects of engine knocks that causes loses of output power and damages the engine.

\section{Volumetric efficiency}

The volumetric efficiency increases with an increase of compression ratio and engine speed as illustrated in figure (11). The reported volumetric efficiency for LPG was $76 \%$ and $79.9 \%$ for gasoline at $3500 \mathrm{rpm}$ for compression ratio of $8: 1$. It was $80 \%$ for LPG and $82.9 \%$ for gasoline at compression ratio of 9.9:1. it was $81.3 \%$ for LPG and $84.9 \%$ for gasoline at compression ratio of $10.25: 1$. While, it was $83.3 \%$ for LPG and $87.2 \%$ for gasoline at compression ratio of 15:1. The maximum percentage difference of volumetric efficiency at $3500 \mathrm{rpm}$ between gasoline and LPG was 4.88, 4.65\%, 4.2\% and 5.3\% for compression ratio 8:1,9.9:1,10.25 and 15:1 respectively. Increasing compression ratio improved engine volumetric efficiency for LPG fuel and bring it close to gasoline. Volumetric efficiency of 
gasoline is higher than LPG because gasoline is injected as a liquid phase and as it vaporizes, it cools air, thus produces improved volumetric efficiency. The vaporized LPG fuel leads to discharge intake air because of its gaseous nature that occupied the space and reduced the amount of air entering in the engine cylinder. Most of the LPG conversion injects the fuel at intake system or intake manifold and the vaporization of fuel depends on few factors such as pipes thermal insulation, ambient air and liquid fuel temperatures, shape and dimensions of the intake system, heat of vaporization of the fuel, load and rotational speed of the engine. Pumping loss associated with conversion system hardware also is the reason to loss part of volumetric efficiency.

\section{In-cylinder pressure}

Same trend for cylinder pressure behavior via crank angle is indicated for both LPG and gasoline, except the differences in the value and timing of peak pressure which depends on the difference in brake power, engine speed, and compression ratio as shown in figure (12). It can be seen that, as engine speed increases, maximum pressure increases reaching its maximum value at $3000 \mathrm{rpm}$. The increase of speed from 1000 to $3000 \mathrm{rpm}$, causes an increase in the maximum pressure from (56.2 to 60) bar for gasoline and from (53.8 to 58) bar for LPG at compression ratio 8:1. For compression ratio 9.9:1, the maximum pressure increases from (62.5 to 65.6) bar for gasoline and from (60 to 64.12) bar for LPG. For compression ratio 10.25:1, the maximum pressure increases from (66 to 70.8) bar for gasoline and from (63.25 to 68.8) bar for LPG. While that for compression ratio 15:1, the maximum pressure increases from (69.7 to 74.7) bar for gasoline and from (73.5 to 68.8) bar for LPG at brake power equals to $10 \mathrm{~kW}$. This is due to high flame speed for gasoline fuel and higher content of carbon atoms than LPG, therefore the produced energy is higher. That causes clear reduction in the combustion duration.

\section{Exhaust gas temperature}

Gasoline exhaust gas temperature increases with increased engine speed and compression ratio. Similar trends but with lower values is observed when LPG fuel is used for the same brake power and engine speeds as shown in figure (13). The maximum exhaust gas temperature reported is $680.3{ }^{\circ} \mathrm{C}$ for $\mathrm{LPG}$ fuel while that for gasoline is $715.6^{\circ} \mathrm{C}$ at compression ratio equals to $8: 1$. For compression ratio of 9.9:1 was $706{ }^{\circ} \mathrm{C}$ for LPG fuel and $741.4^{\circ} \mathrm{C}$ for gasoline. For compression ratio of $10.25: 1$ was $742{ }^{\circ} \mathrm{C}$ for LPG fuel and $773{ }^{\circ} \mathrm{C}$ for gasoline, While that for compression ratio of $15: 1$ was $762.5^{\circ} \mathrm{C}$ for LPG fuel and $794.1^{\circ} \mathrm{C}$ for gasoline. The increase in exhaust gas temperature is due to the increase in peak temperature and peak pressure, causes faster running of fuel combustion. Gasoline produced higher exhaust gas temperatures taking advantages of its higher volumetric efficiency and its higher heating value. The depreciation of LPG volumetric efficiency causes a reduction in exhaust temperature. Many parameters operated against LPG, lower pressure and lower temperature inside combustion chamber results a temperature rise with increasing of the speed to inject largest quantity of fuel. Gases temperature is gradually decreased as they pass through the converter catalytic and muffler, due to heat lost to atmosphere by convection, conduction and radiation.

\section{Comparison between computational and experimental results}

Figure (14) shows a comparison of experimental [Gatea 2019] and computational results of brake specific fuel consumption (gasoline or LPG) against engine speed (rpm) for two compression ratios $(9.9: 1$ and $10.25: 1)$ and for brake power of $10 \mathrm{~kW}$. The results show that as the engine speed increases, the BSFC is decreased gradually to its minimum value at engine speed of $3000 \mathrm{rpm}$, then increases as the speed was increased to $3500 \mathrm{rpm}$. Figure (15) presents the relation between brake power $(\mathrm{kW})$ and engine speed (rpm) for LPG and gasoline fuels for the two-compression ratio (9.9:1 and 10.25:1). Peaks of brake power was indicated at engine speed of $3500 \mathrm{rpm}$ for all experimental and computational results. Brake power 
increases rapidly with increasing of engine speed for each compression ratios equal to 9.9:1 and 10.25:1. While, figure (16) shows the brake thermal efficiency for different values of engine speed (rpm), different operating fuel (LPG and gasoline), brake power (10 kW) and two compression ratio of (9.9:1 and 10.25:1). The peak brake thermal efficiency in all cases is reached at $3000 \mathrm{rpm}$.

\section{CONCLUSIONS}

An extensive investigation of the combustion, cycle, performance parameters and exhaust emissions of SI engine running on gasoline and LPG has been performed in this work. From the obtained results, the following conclusions can be drawn:

1. LPG fuel improves the engine brake specific fuel consumption and brake thermal efficiency but reduces the brake power compared to gasoline fuel. The maximum of percentage deviation BSFC in gasoline fuel compare with LPG fuel reported is $3.11 \%$ for engine brake power equals to $10 \mathrm{~kW}$ when compression ratio equal 9.9:1.

2. The maximum cylinder pressures predicted for LPG are lower than that produced by gasoline fuel. The maximum pressure from (62 to 71.5) bar for gasoline and from (60 to 67.12) bar for LPG when 9.9:1 compression ratio and for equals to $10 \mathrm{~kW}$. LPG reduces the engine volumetric efficiency compared to that produced by gasoline fuel, thus, engine effective power is decreased. The maximum volumetric efficiency in all cases is reached at $3500 \mathrm{rpm}$ and for equals to $10 \mathrm{~kW}$. The volumetric efficiency was $76.8 \%$ for LPG and $85.9 \%$ for gasoline when compression ratio equals to 9.9:1.

3. Compression ratio and equivalence ratio have a significant effect on both performance and emission characteristics of the engine and have to be carefully designed to achieve the best engine performance characteristics. The equivalence ratio of gasoline is higher than LPG, the maximum difference of equivalence ratio brake power equals to $10 \mathrm{~kW}$ between gasoline and LPG was 3.65\% and 6.6\% for compression ratio 9.9:1 and 10.25 respectively.

4. The exhaust gas temperature increases with the increase of engine speed, compression ratio and brake power. Similar trends are also observed when LPG fuel is used. The exhaust gas temperatures for gasoline fuel is higher than that for LPG fuel at the same brake power and engine speed. The maximum exhaust gas temperature reported is $706^{\circ} \mathrm{c}$ for LPG fuel while that for gasoline is $741.4^{\circ} \mathrm{c}$ at point 1 for brake power on engine equals to $10 \mathrm{~kW}$ and compression ratio equals to $9.9: 1$.

\section{Acknowledgment}

This work was supported and funded by University of Baghdad, College of Engineering, Department of Mechanical Engineering and Ministry of petroleum- Gas Filling Company, Contract Company Number (N/274/97) on $1^{\text {st }}$ March 2017. 
Table 1: Specifications of the test engine.

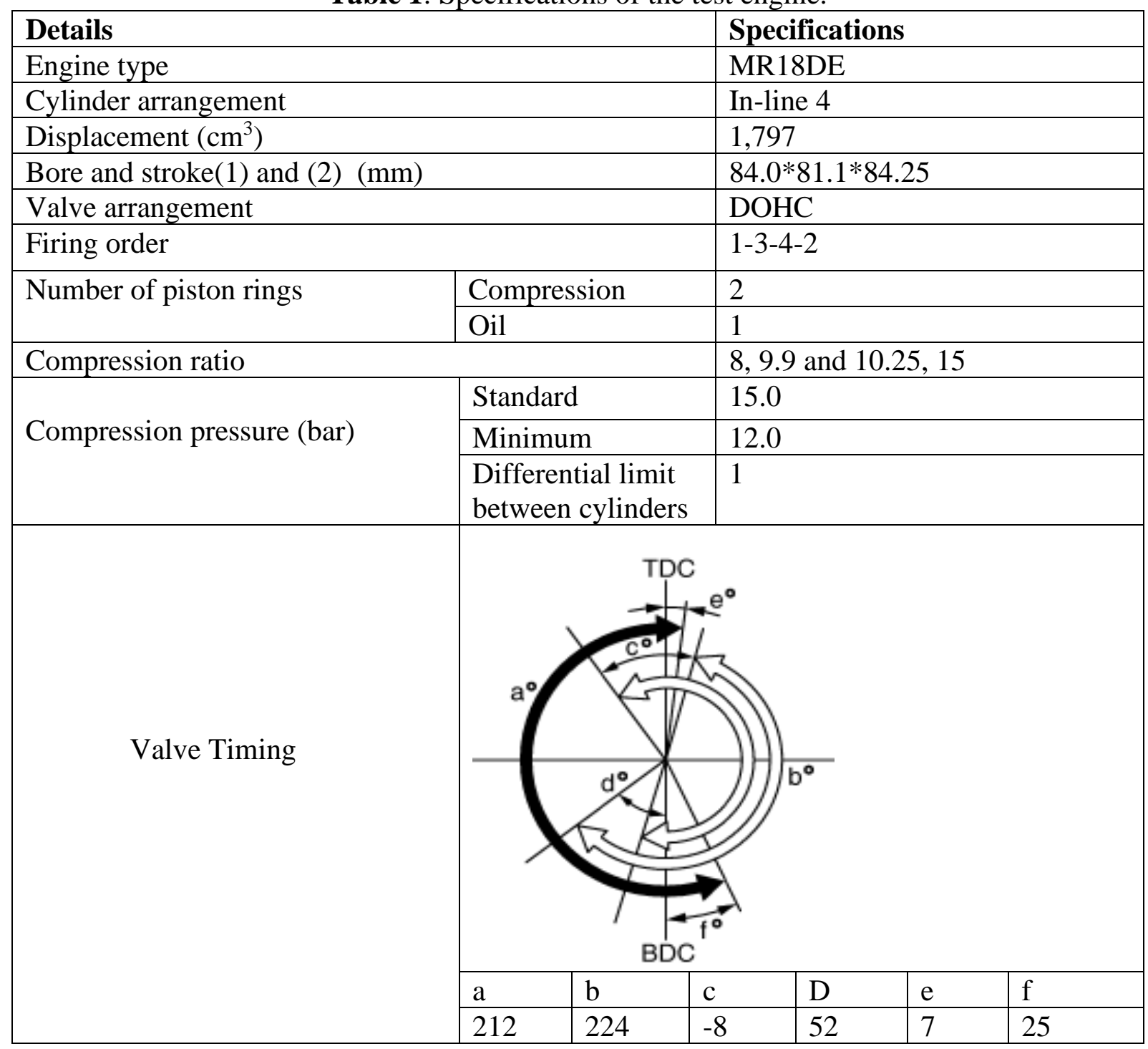

Table 2:Properties of utilized fuels

\begin{tabular}{|l|c|c|}
\hline Properties & LPG & Gasoline \\
\hline Density at $15^{\circ} \mathrm{C}\left(\mathrm{kg} / \mathrm{cm}^{3}\right)$ & 0.554 & 0.737 \\
\hline Lower Heating Value $(\mathrm{MJ} / \mathrm{kg})$ & 45.25 & 43.96 \\
\hline Octane number & 104 & 82 \\
\hline Boiling temperature $\left({ }^{\circ} \mathrm{C}\right)$ & 2.2 & 210 \\
\hline Vapor pressure at $37.8^{\circ} \mathrm{C}\left(\mathrm{kg} / \mathrm{cm}^{2}\right)$ & $8-10$ & $0.45-0.62$ \\
\hline
\end{tabular}

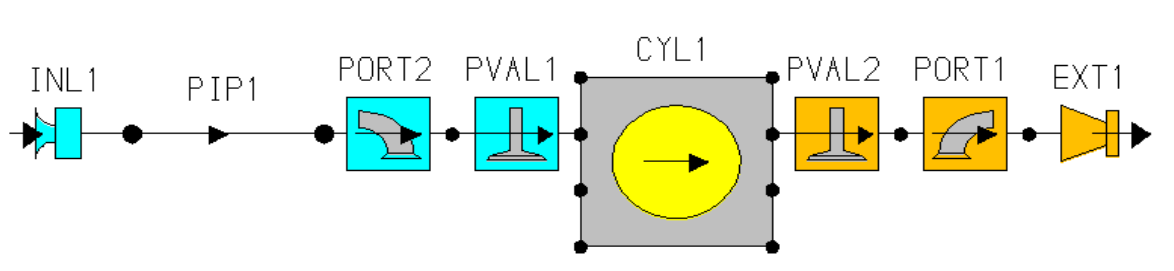

Figure (1): Model of one cylinder 


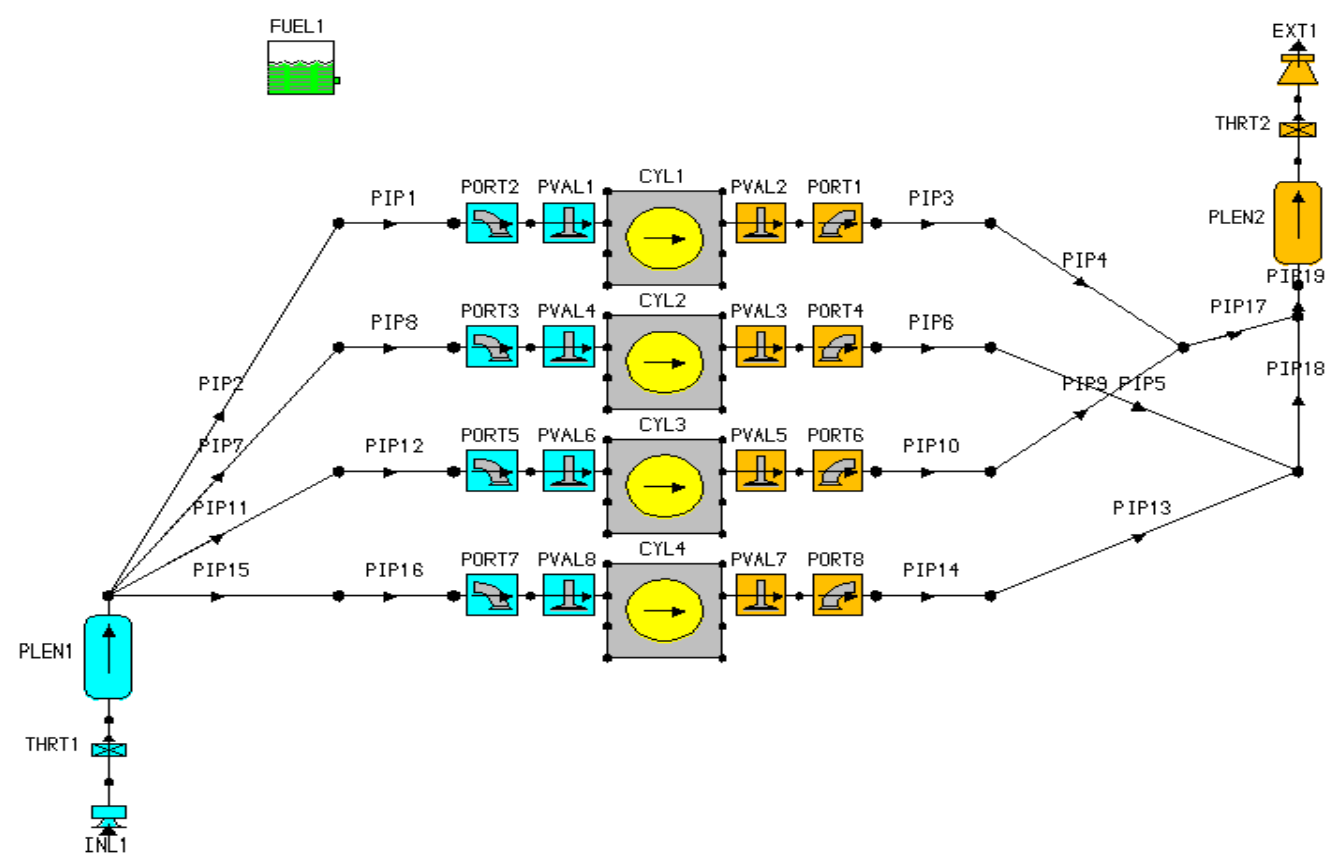

Figure (2): LOTUS model of four cylinder IC engine

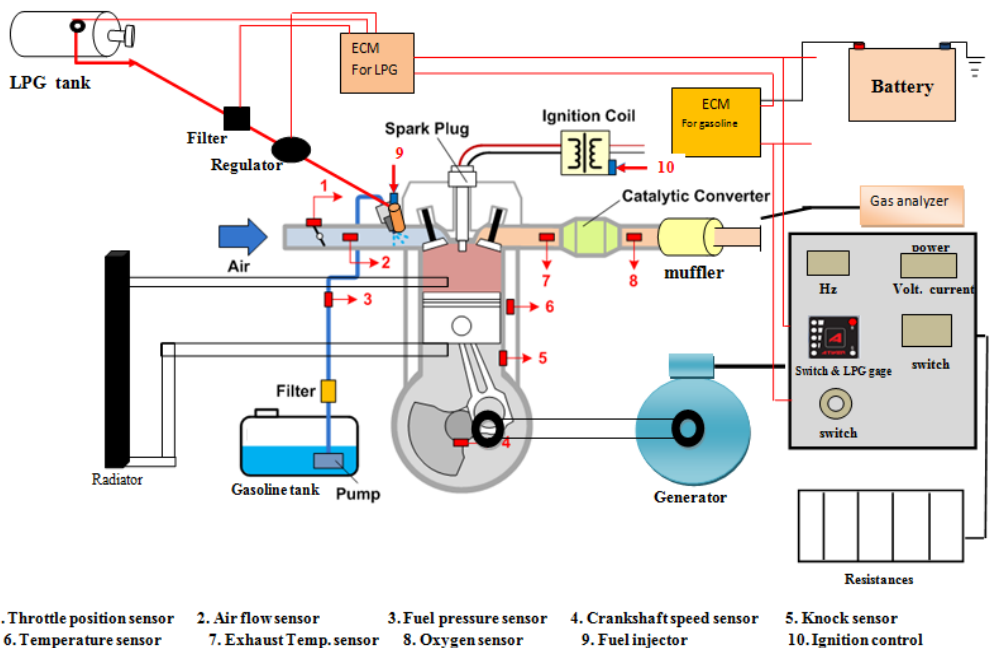

Figure (3): Schematic diagram of experimental setup 


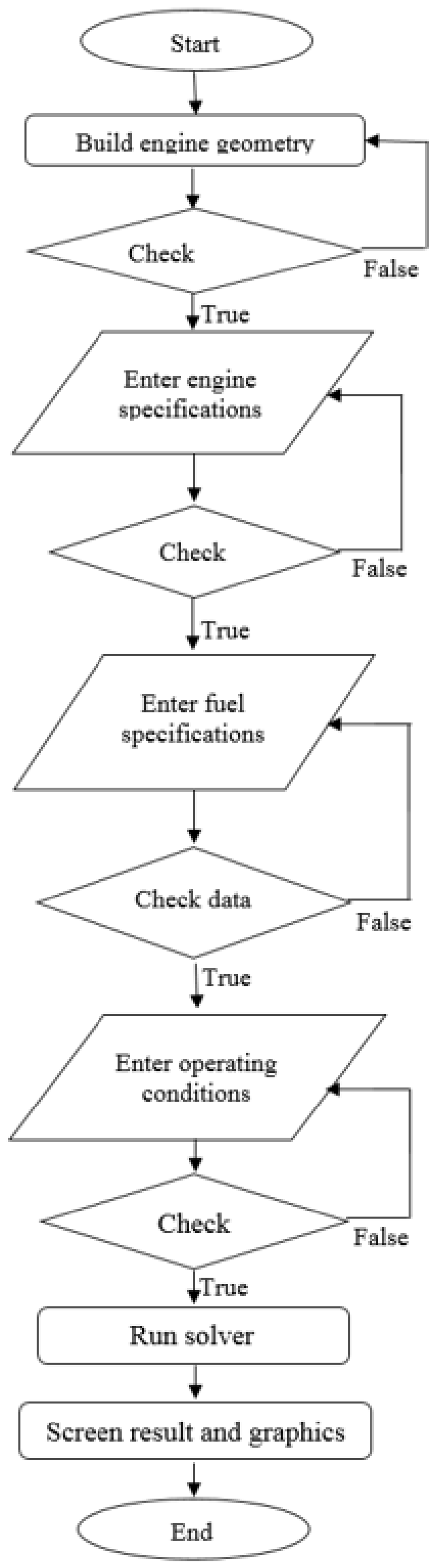

Figure (4): The schematically steps of LOTUS Engine Simulation model. 


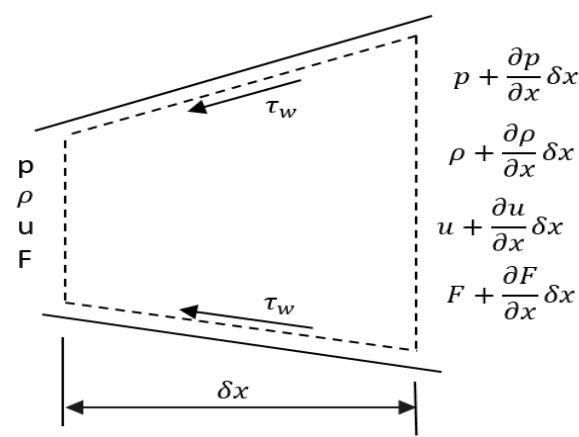

Figure (5): Fluid control volume in duct

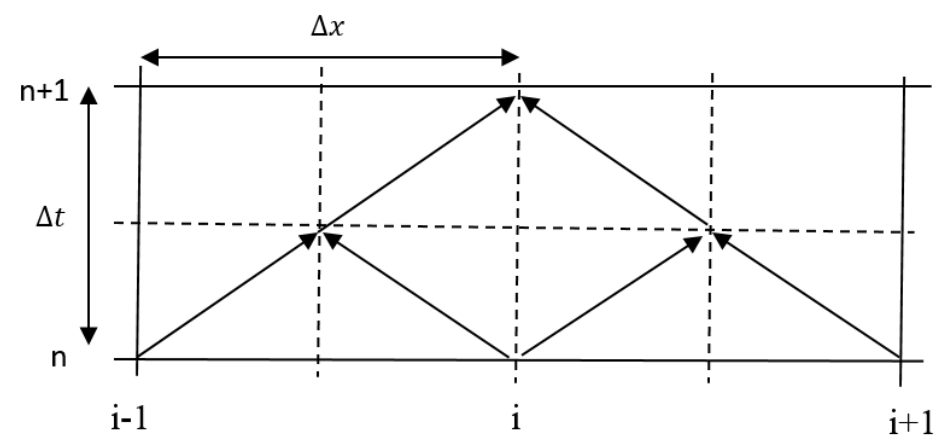

Figure (6): Schematical representation of the two-step Lax-Wendroff scheme.

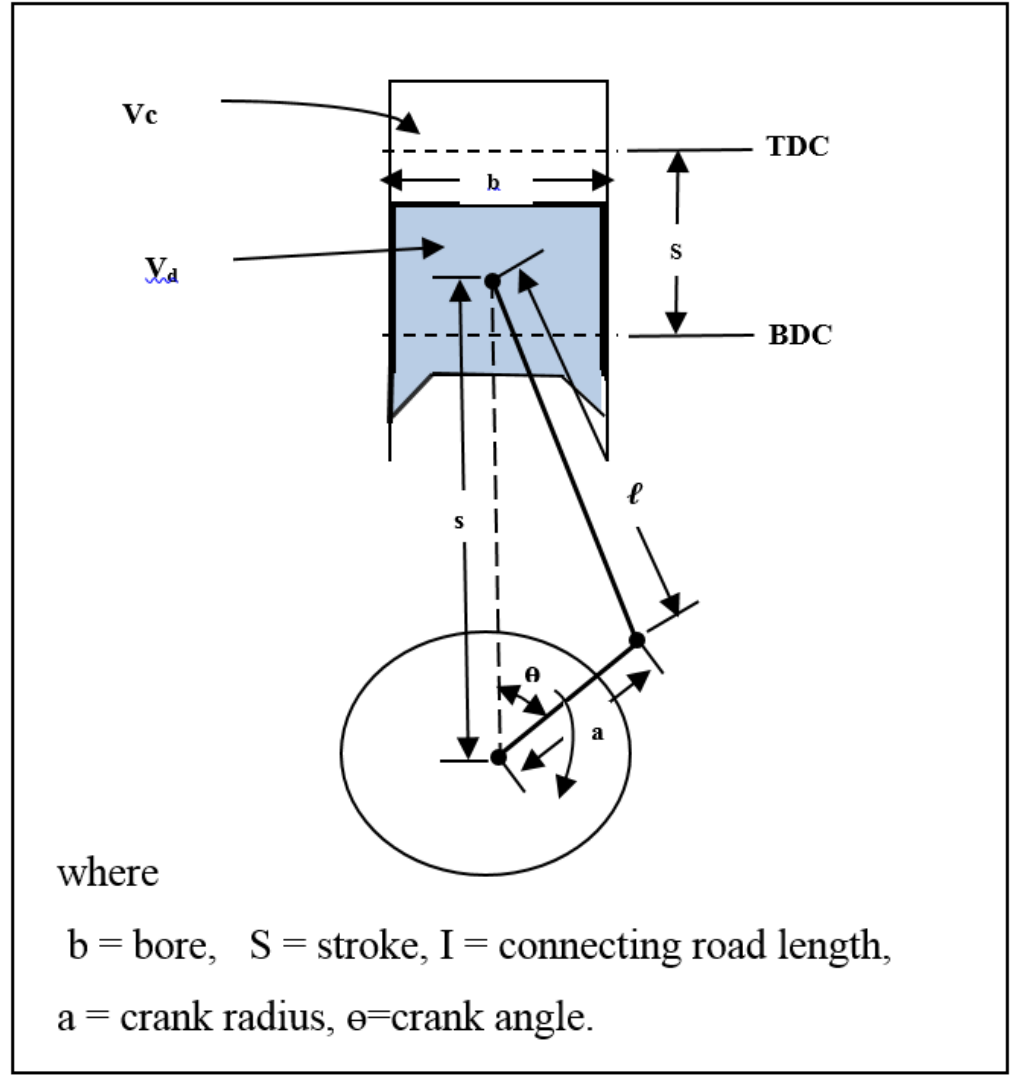

Figure (7): Geometry of cylinder 

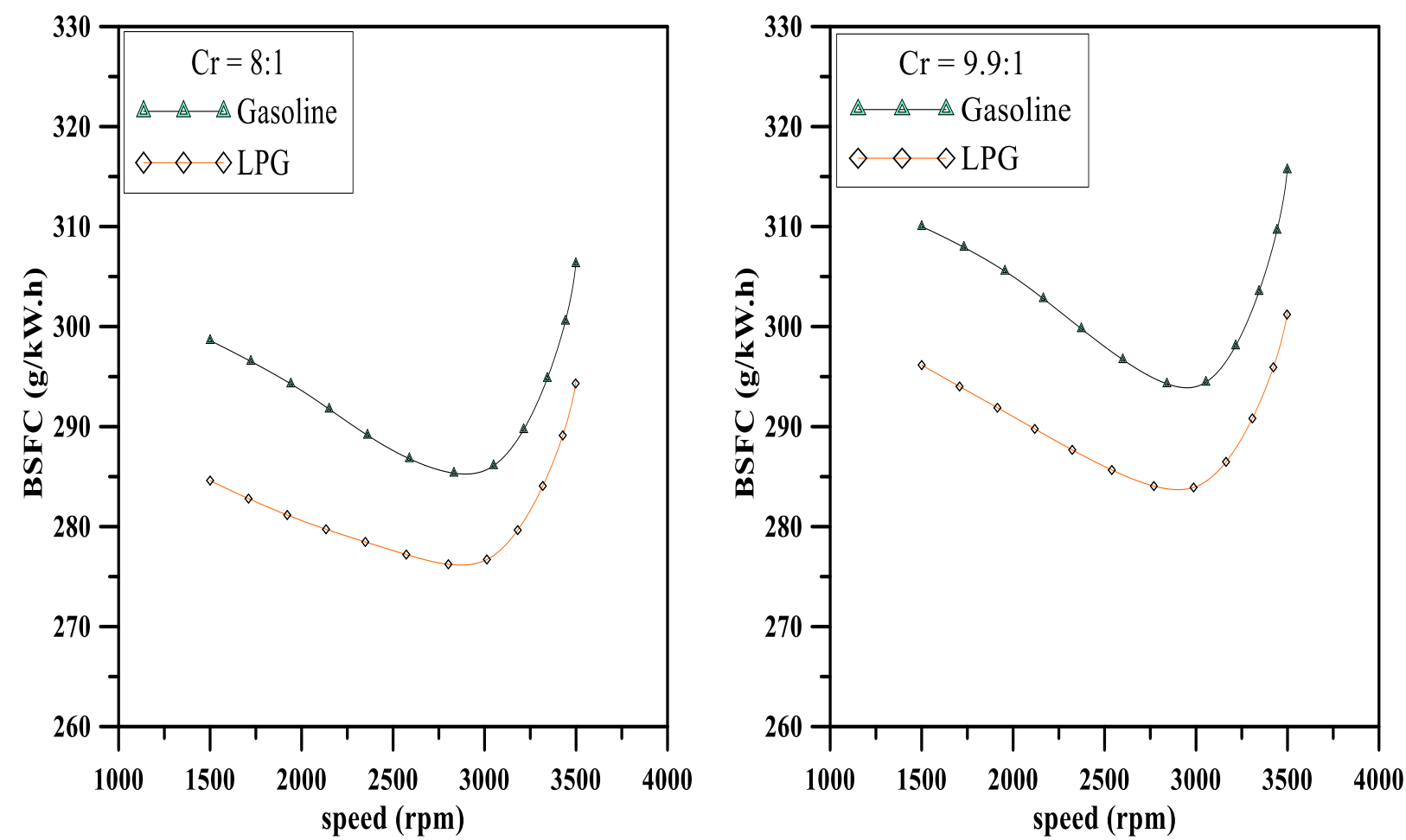

(a)

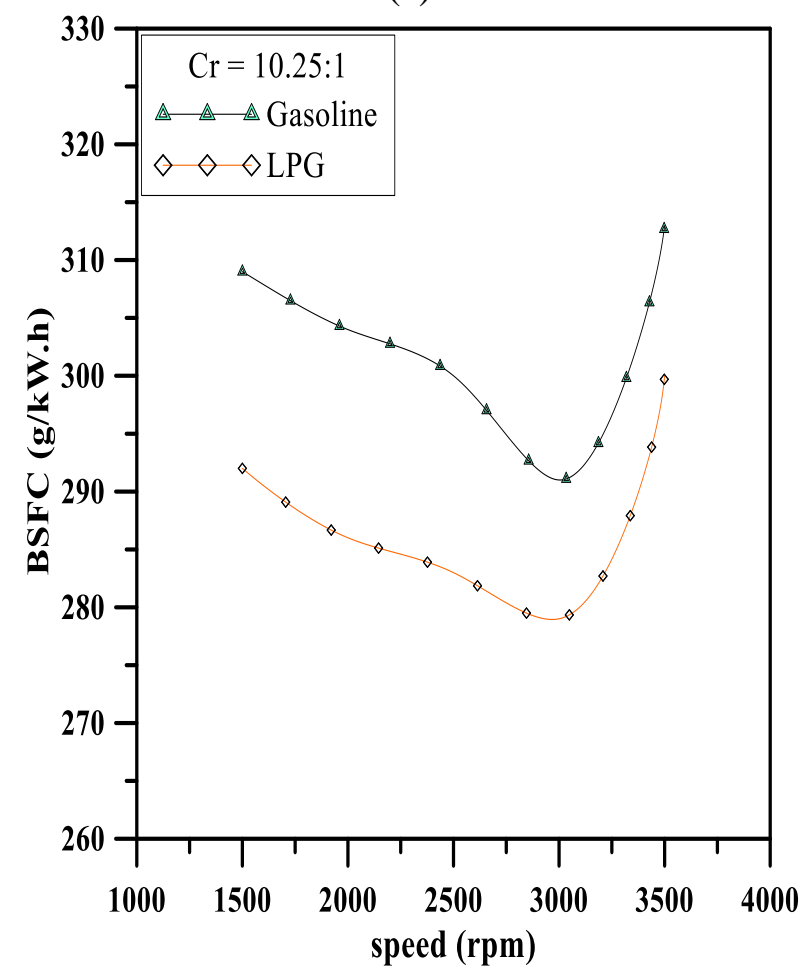

(c)

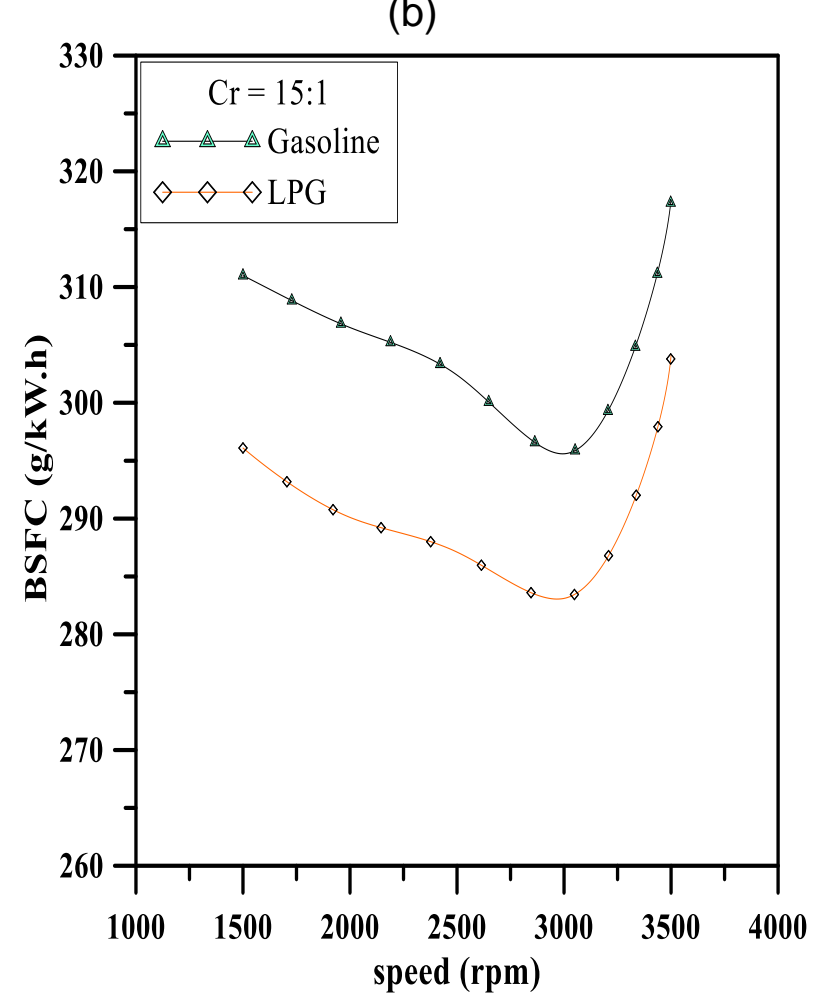

(d)

Figure (8): Variation of brake specific fuel consumption with engine speed for brake power equals to $(10 \mathrm{~kW})$. 


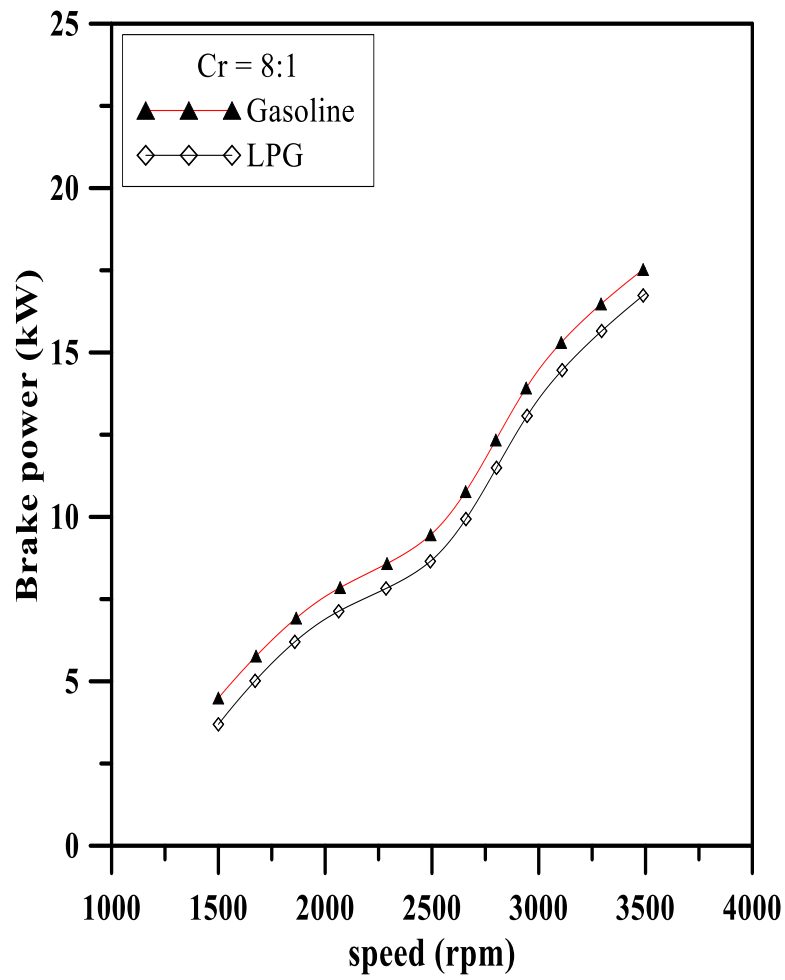

(a)

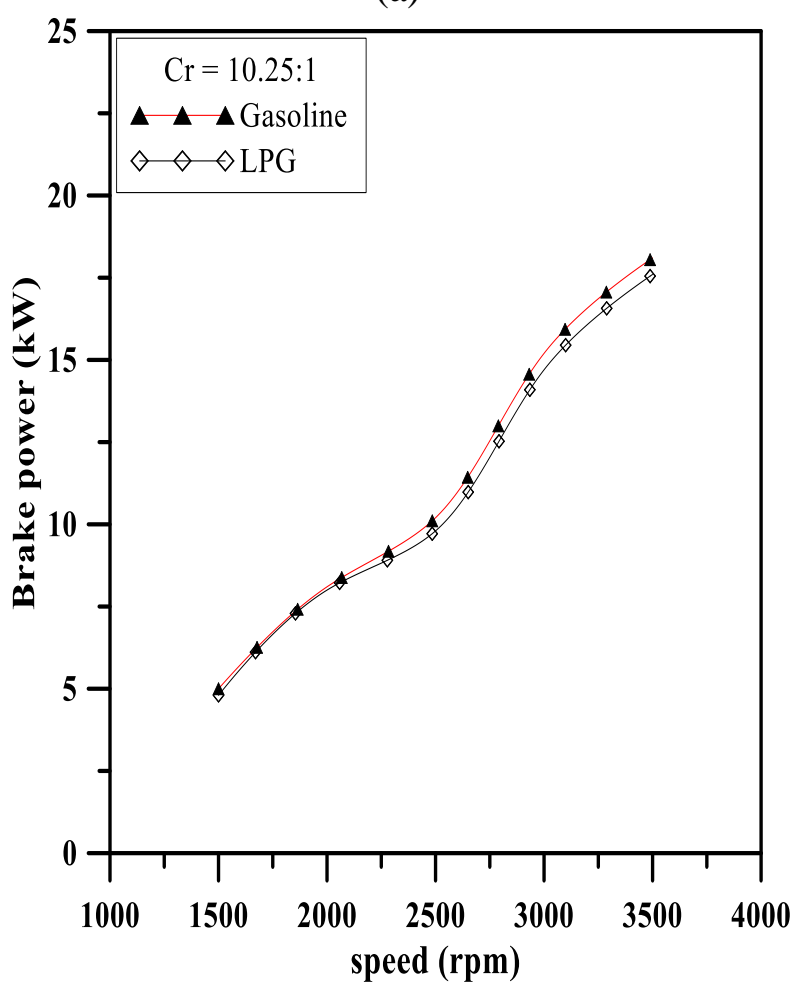

(c)

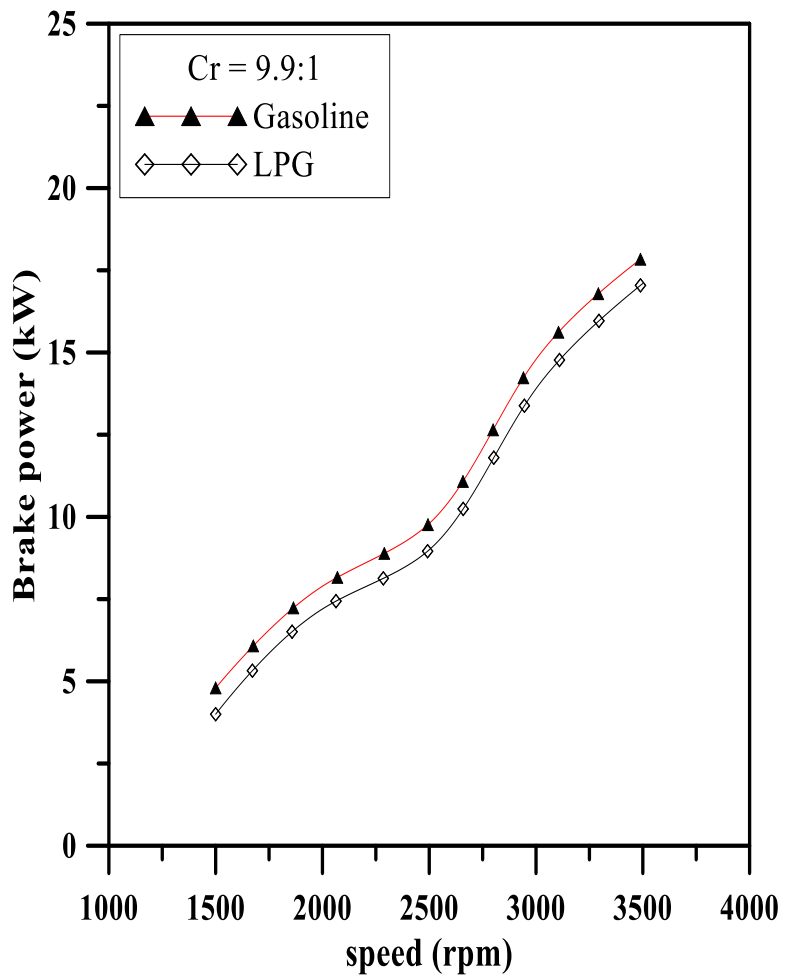

(b)

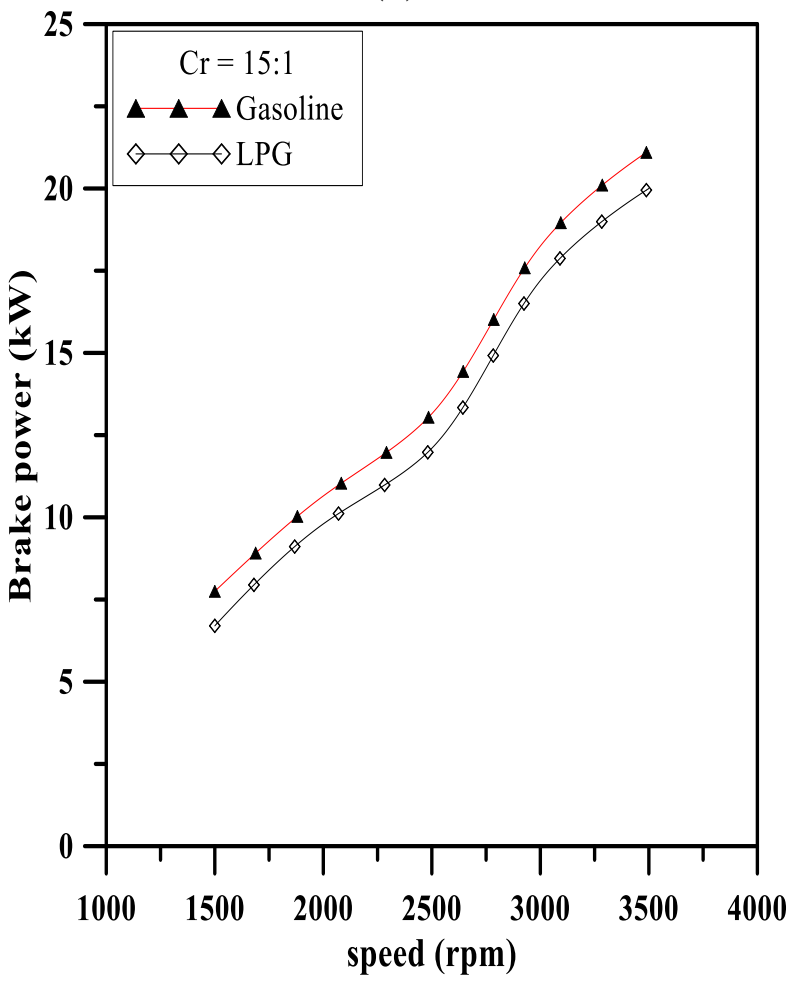

(d)

Figure (9): Variation of brake power versus engine speed. 


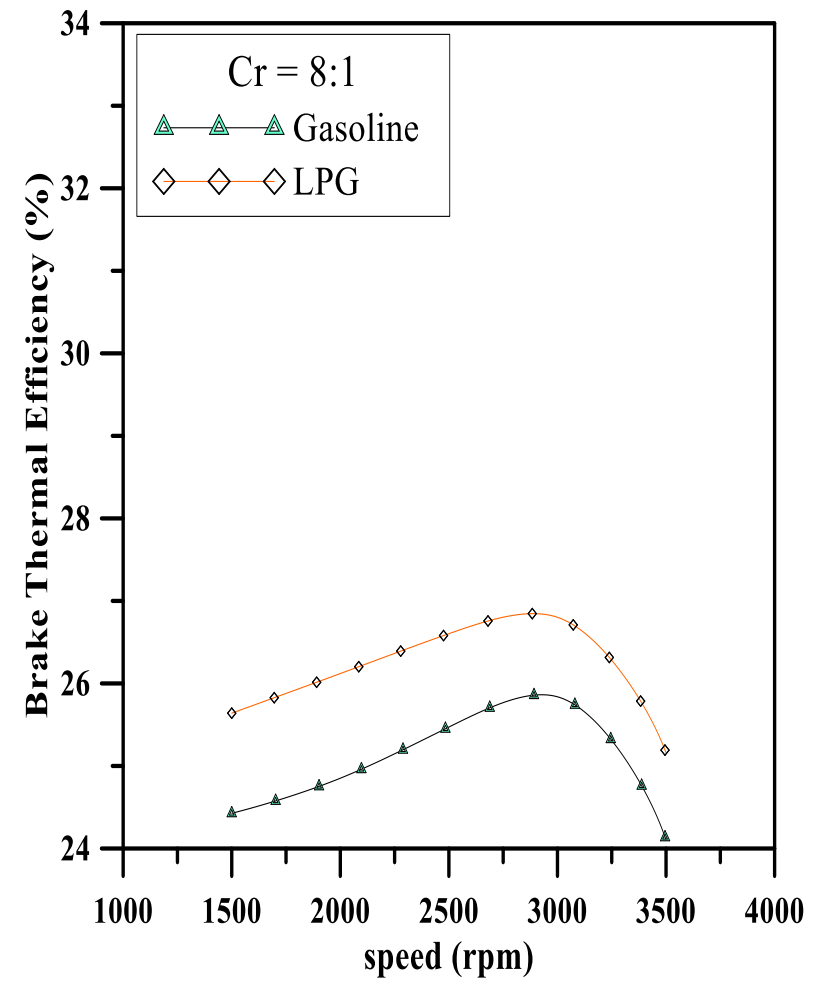

(a)

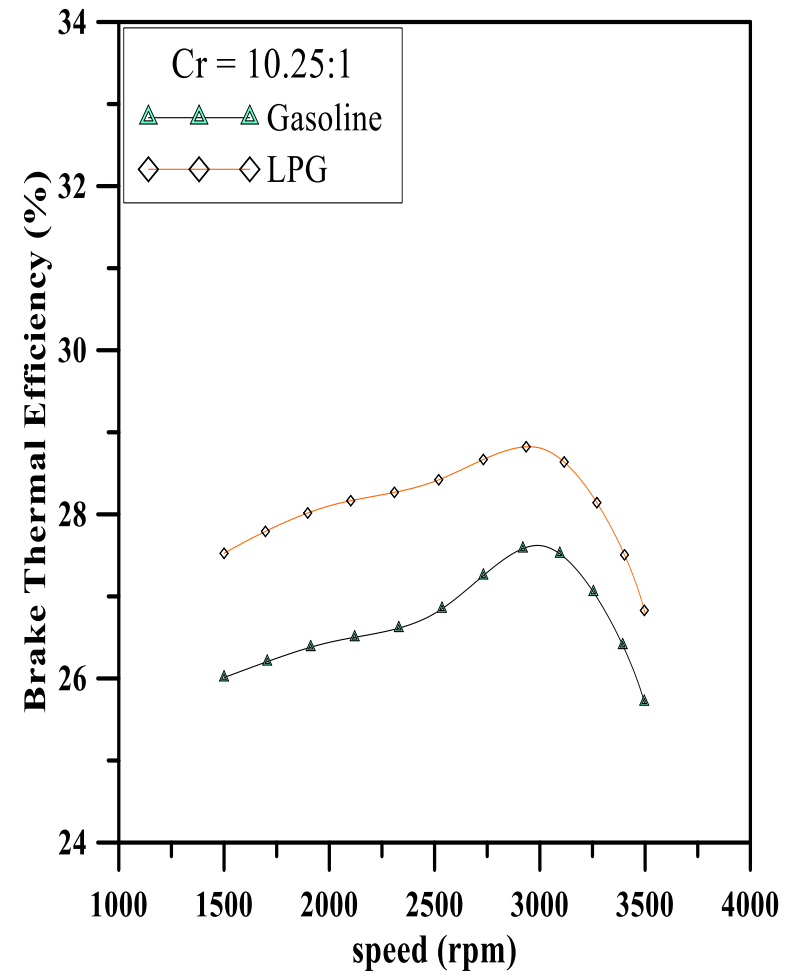

(c)

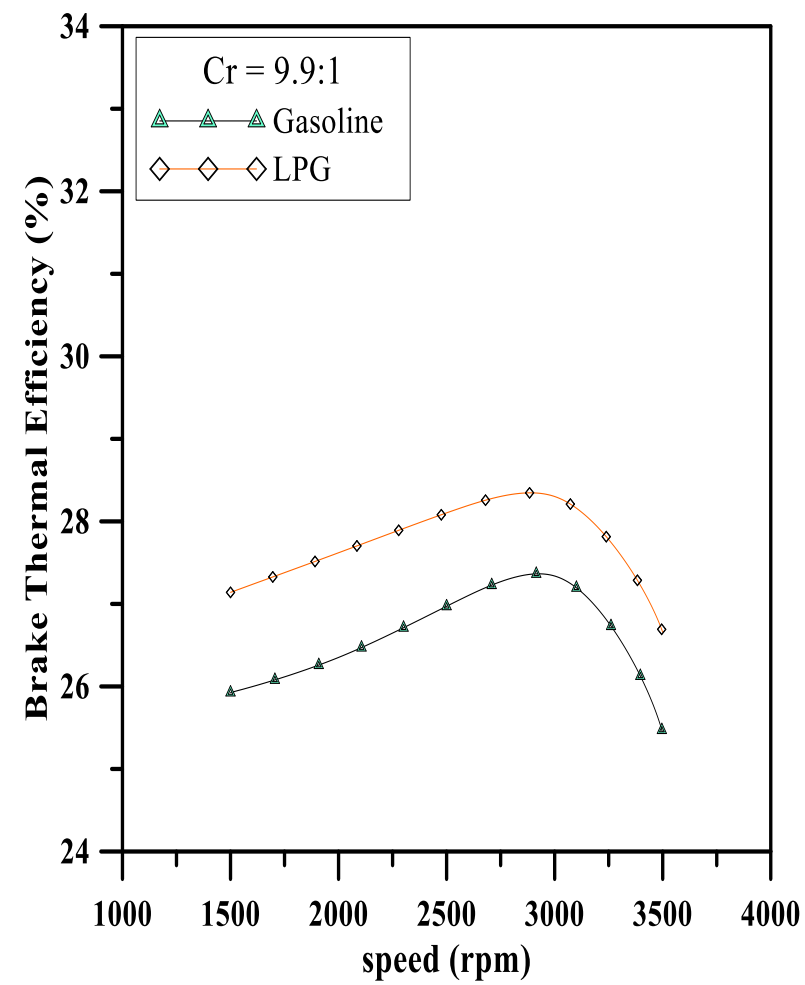

(b)

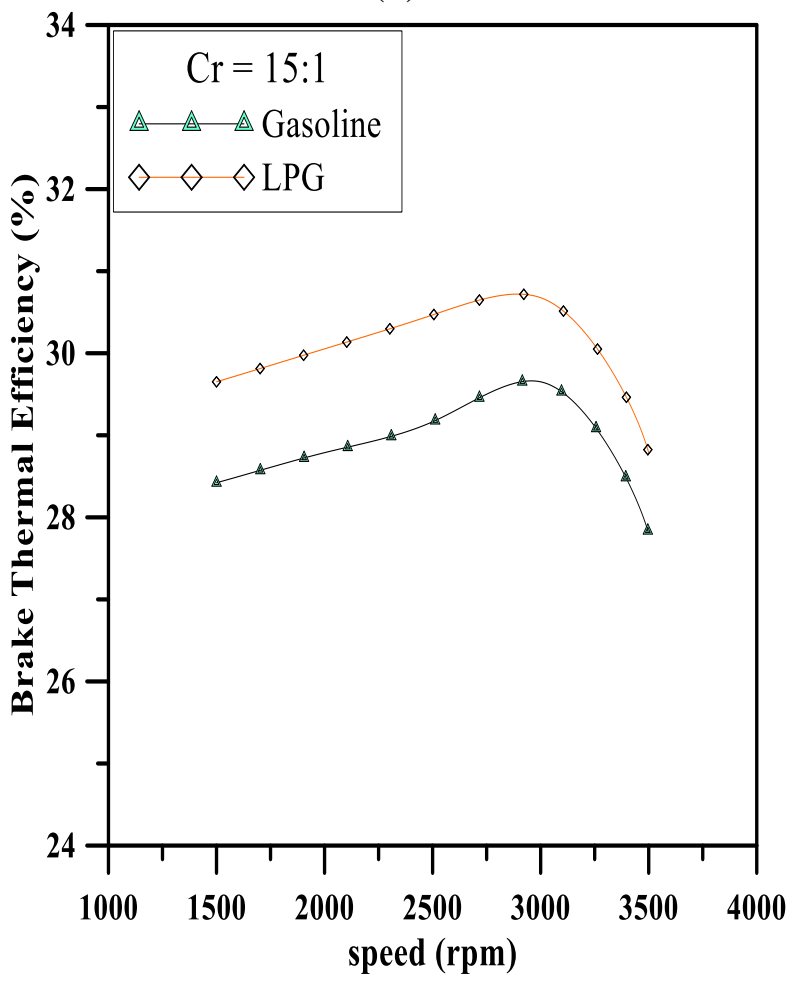

(d)

Figure (10): Variation of brake thermal efficiency versus engine speed for brake power equals to $(10 \mathrm{~kW})$. 


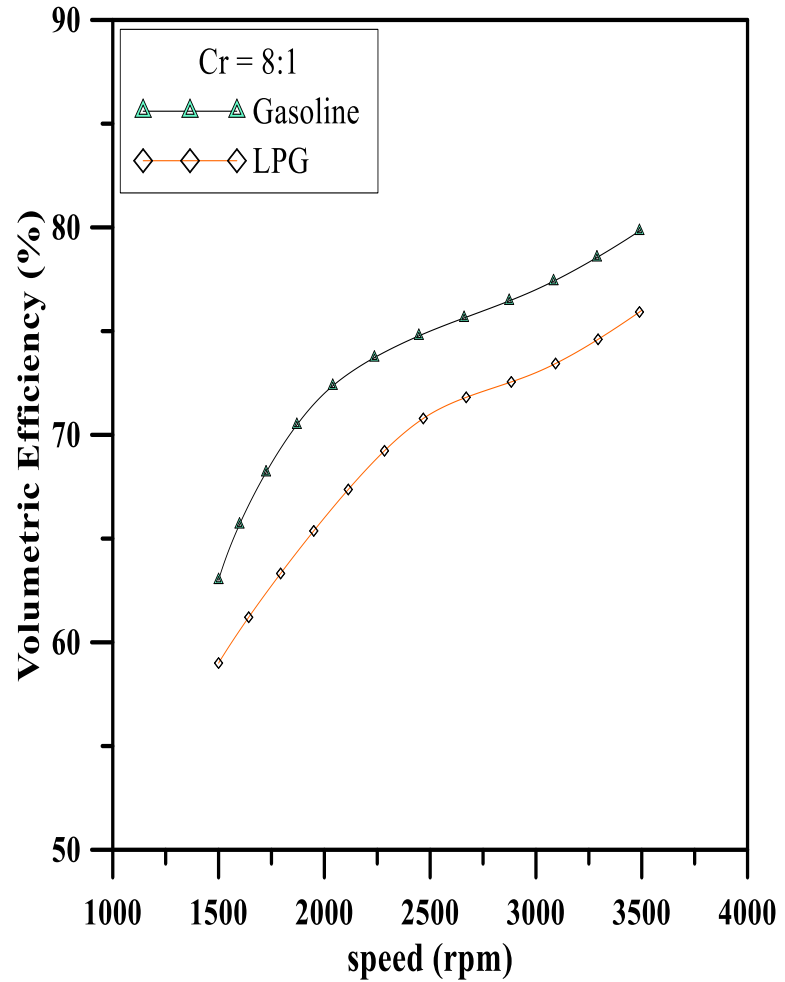

(a)

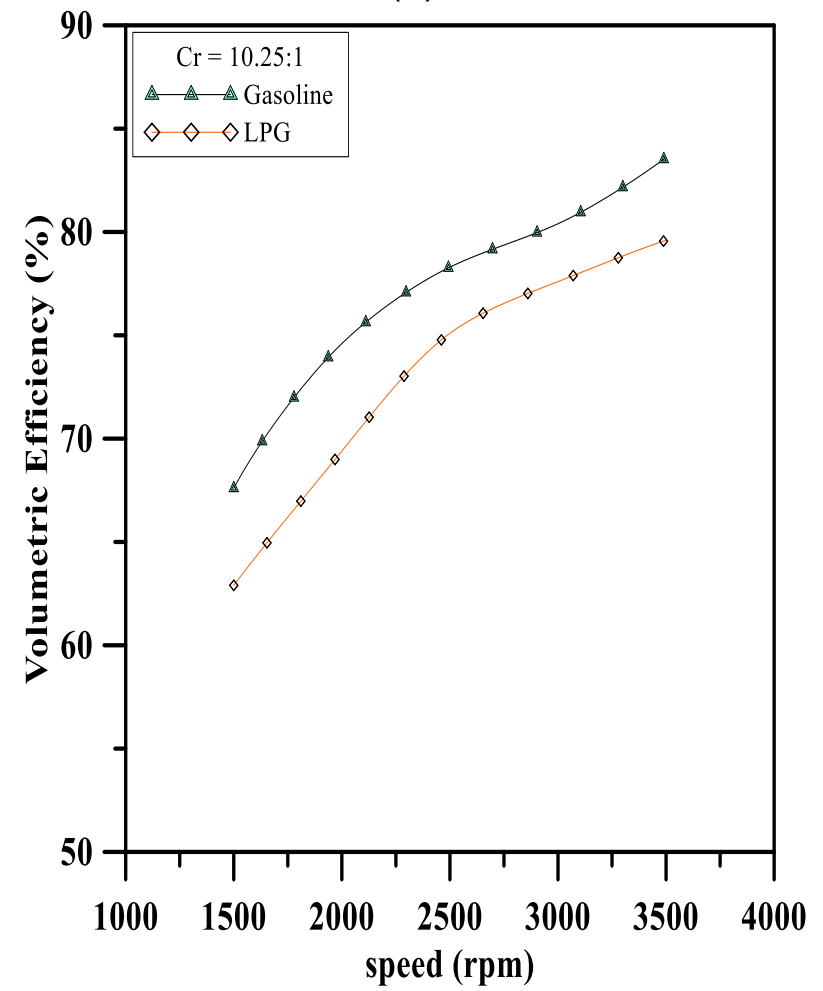

(c)

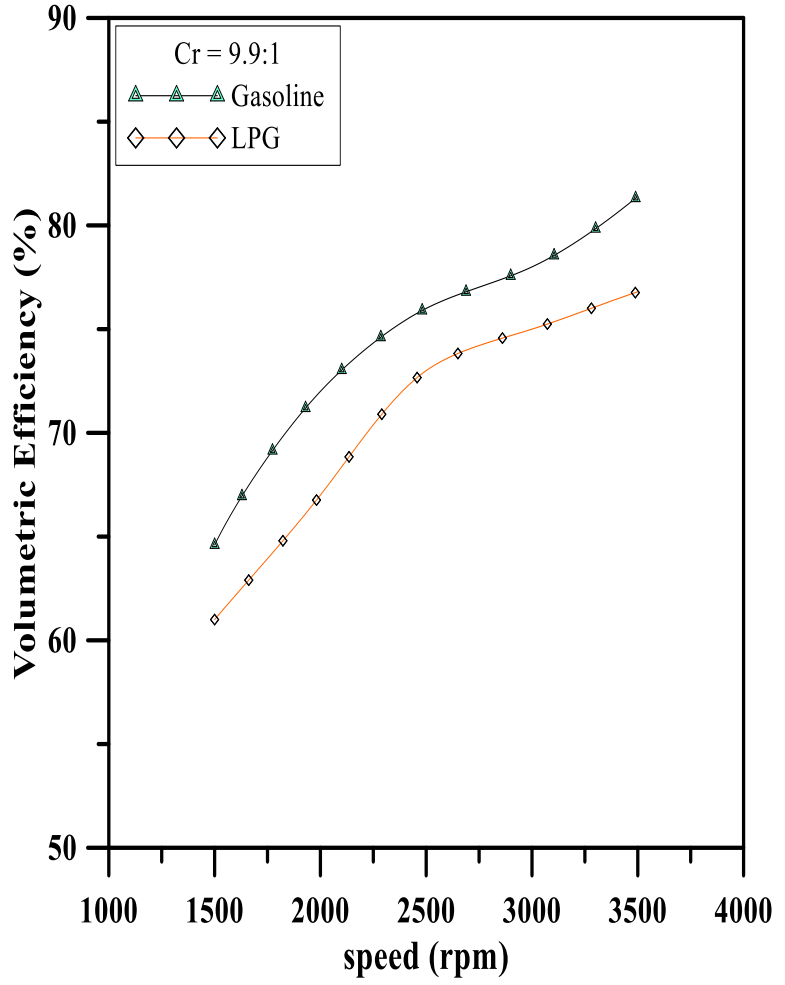

(b)

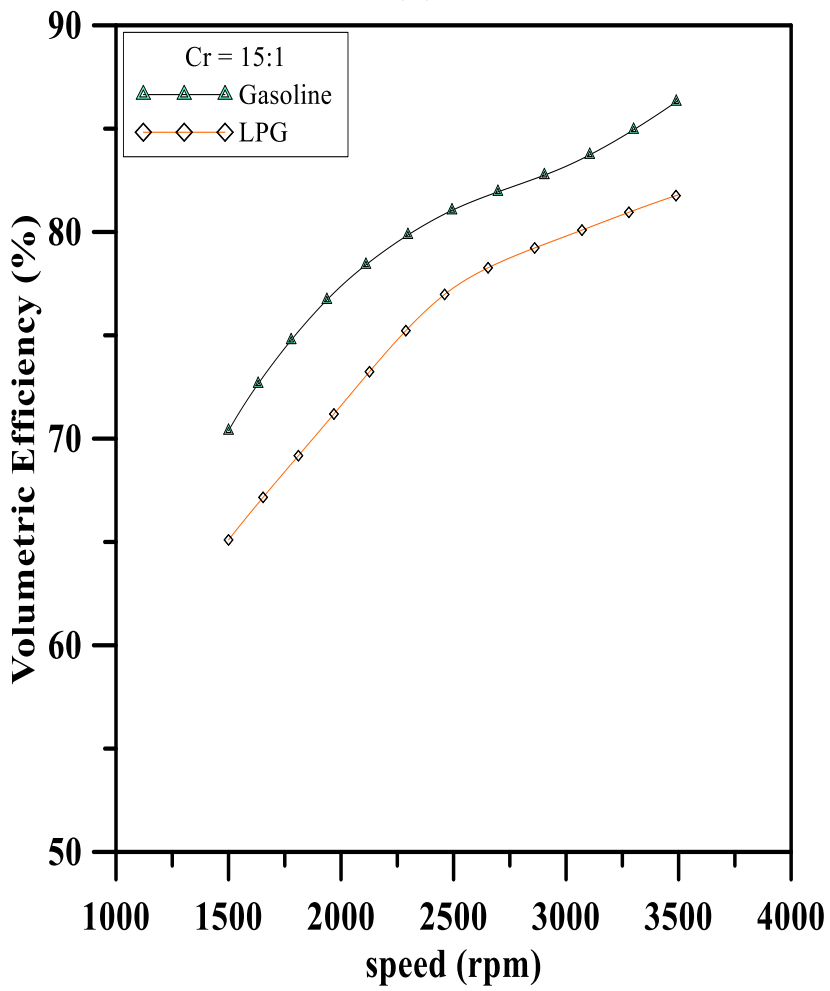

(d)

Figure (11): Variation of volumetric efficiency versus engine speed for brake power equals to (10 kW). 


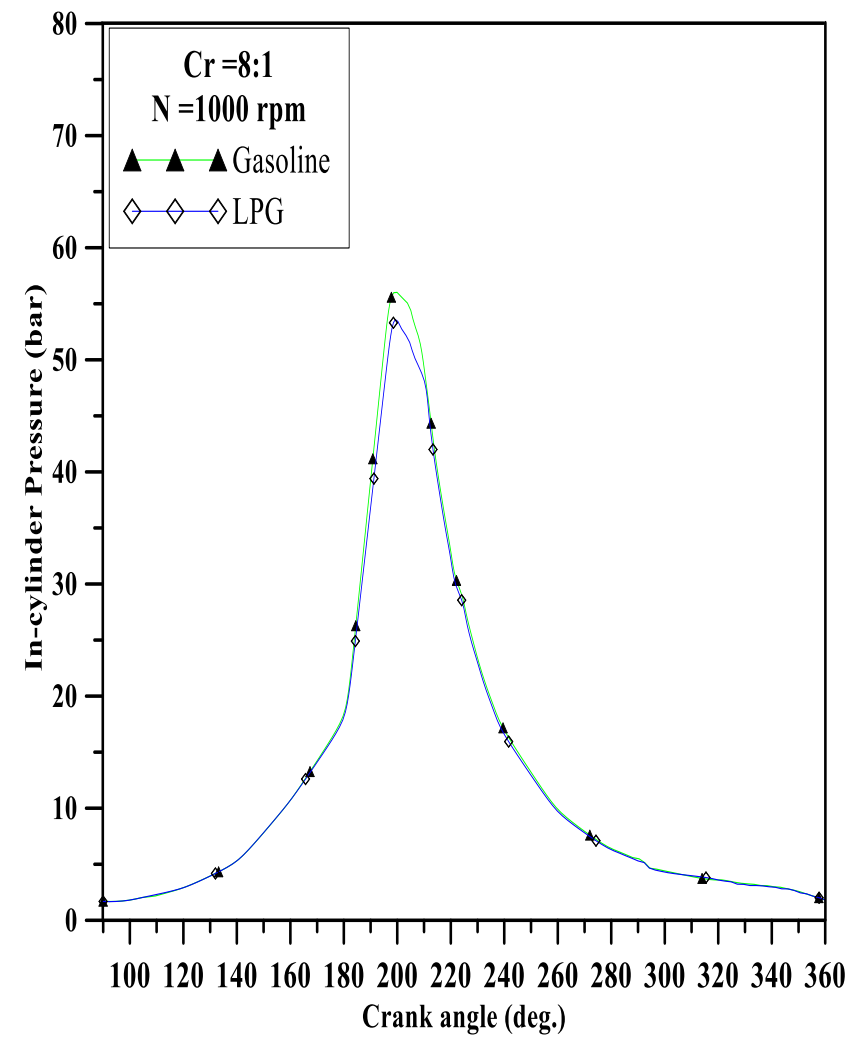

(a)

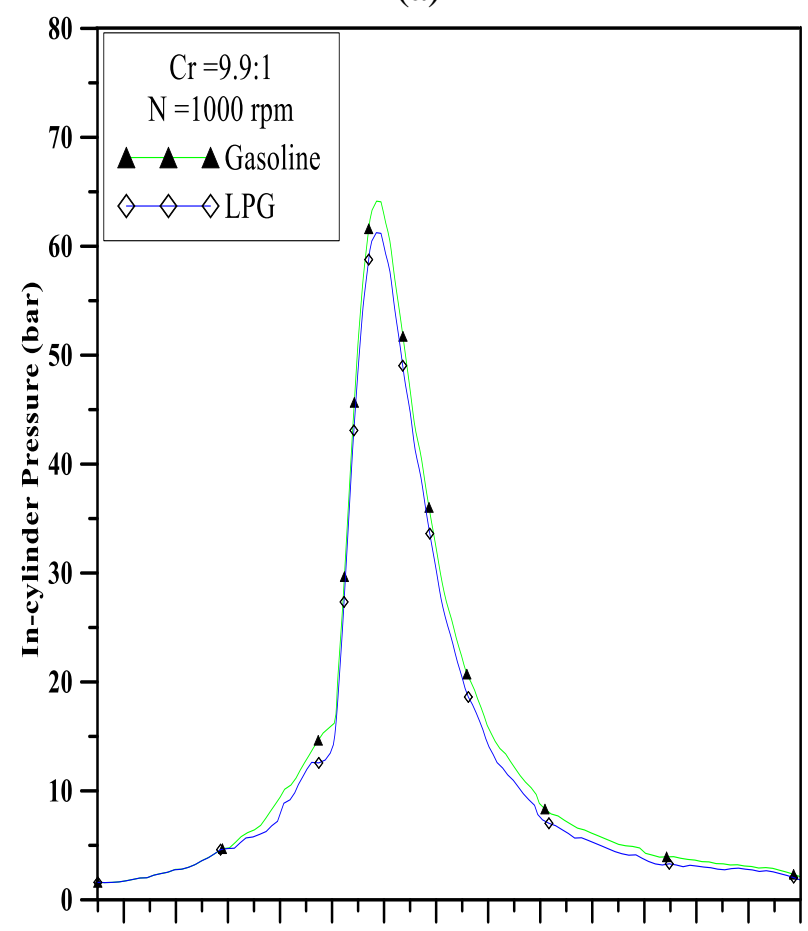

100120140160180200220240260280300320340360 Crank angle (deg.)

(c)

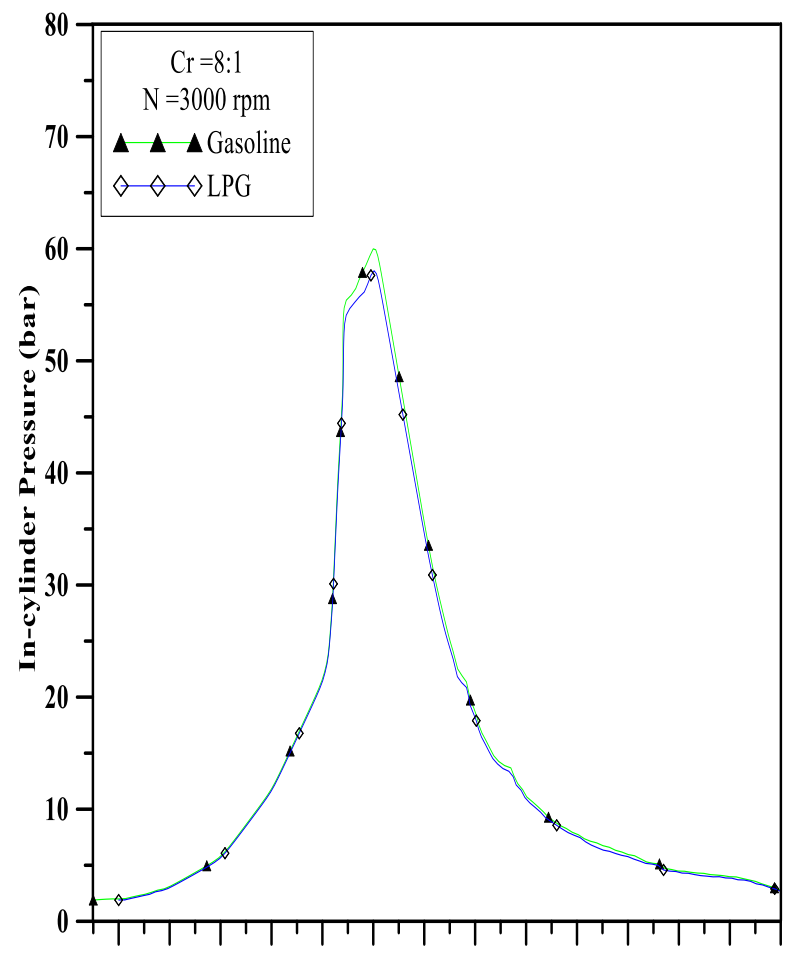

100120140160180200220240260280300320340360 Crank angle (deg.)

(b)

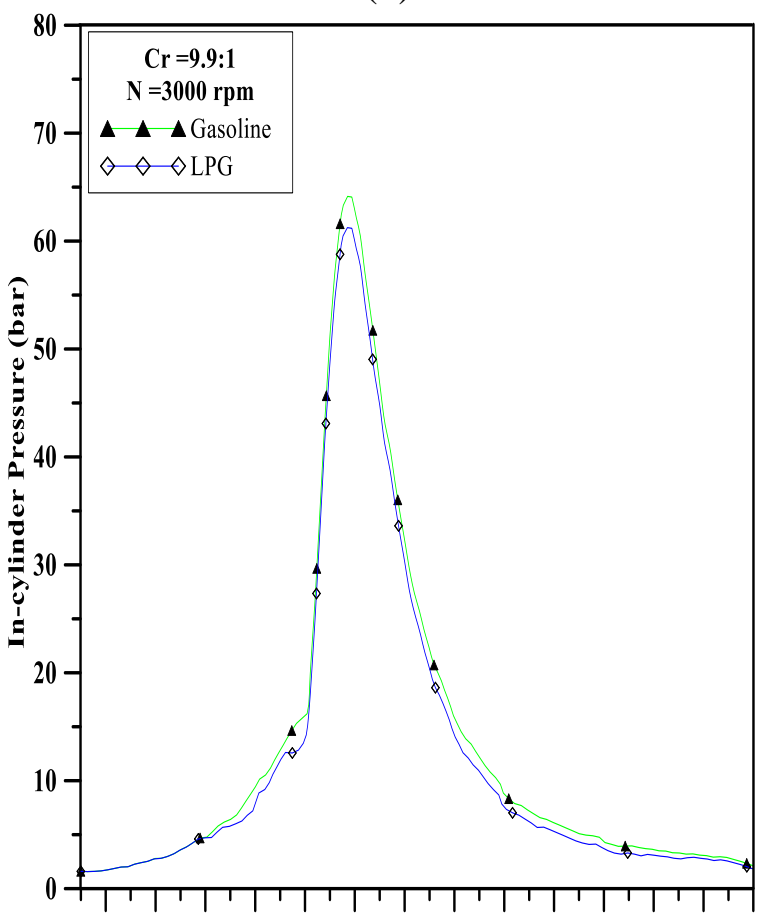

100120140160180200220240260280300320340360 Crank angle (deg.)

(d) 


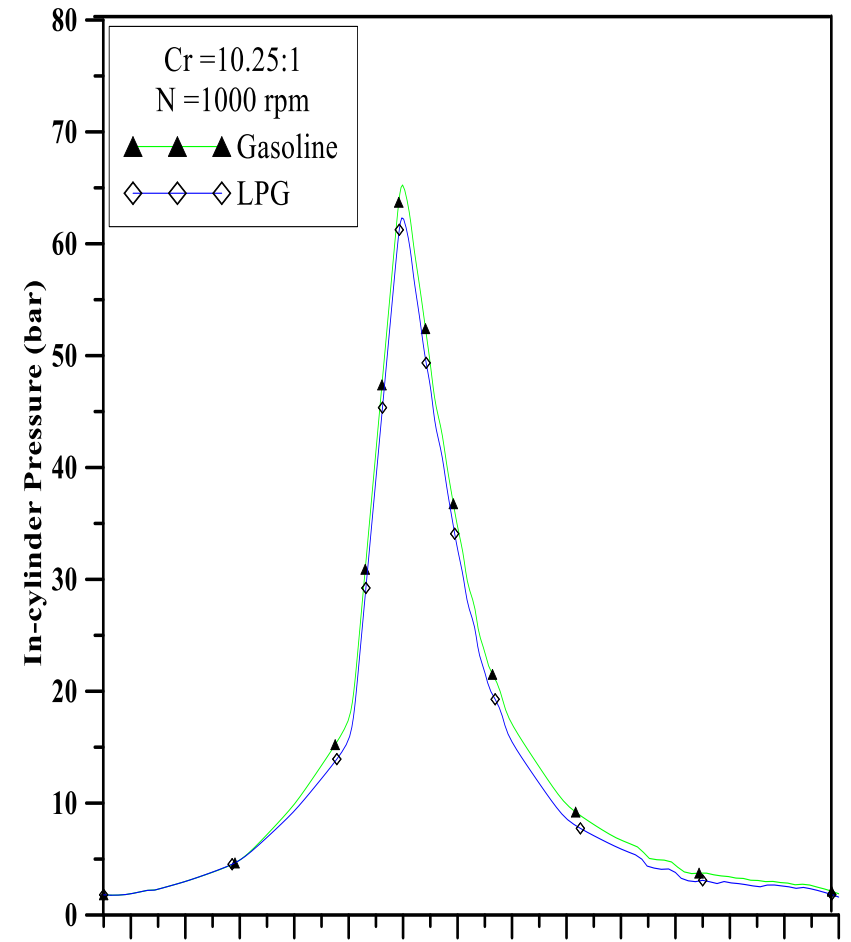

100120140160180200220240260280300320340360 Crank angle (deg.)

(e)

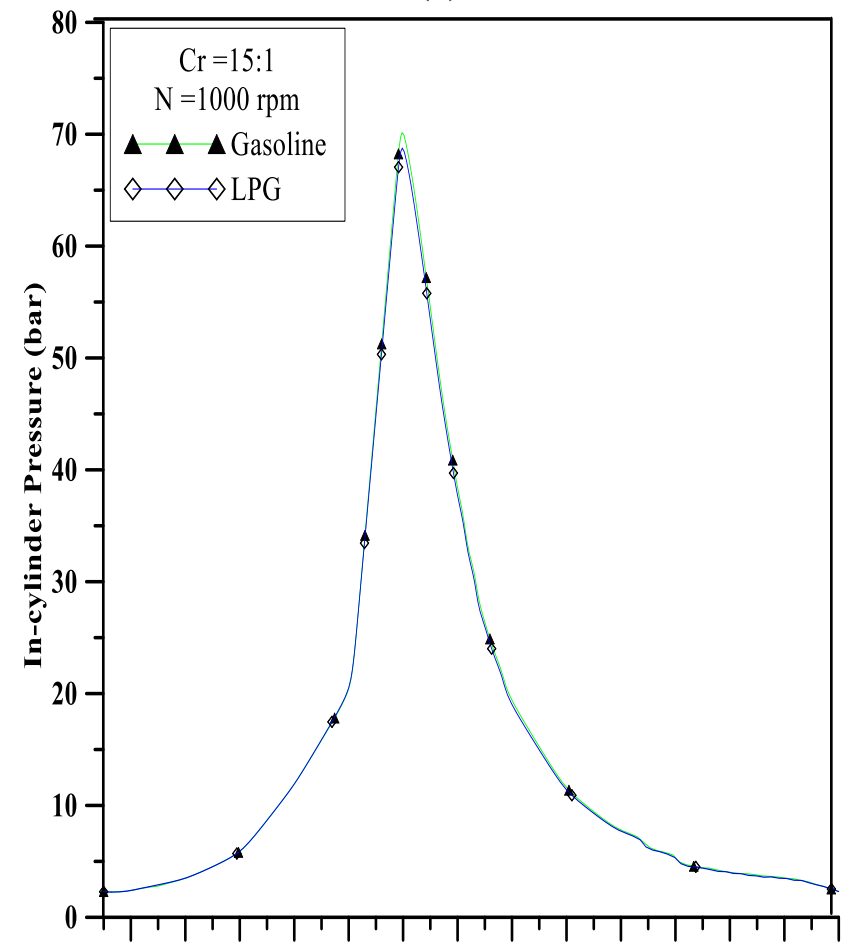

100120140160180200220240260280300320340360 Crank angle (deg.)

(g)

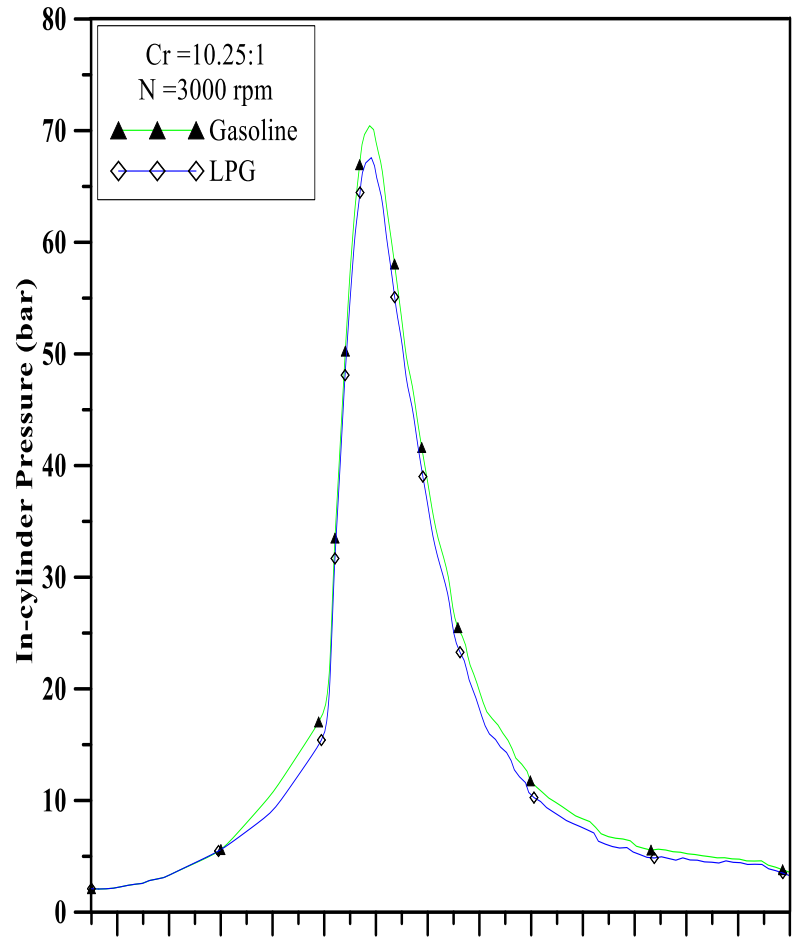

100120140160180200220240260280300320340360 Crank angle (deg.)

(f)

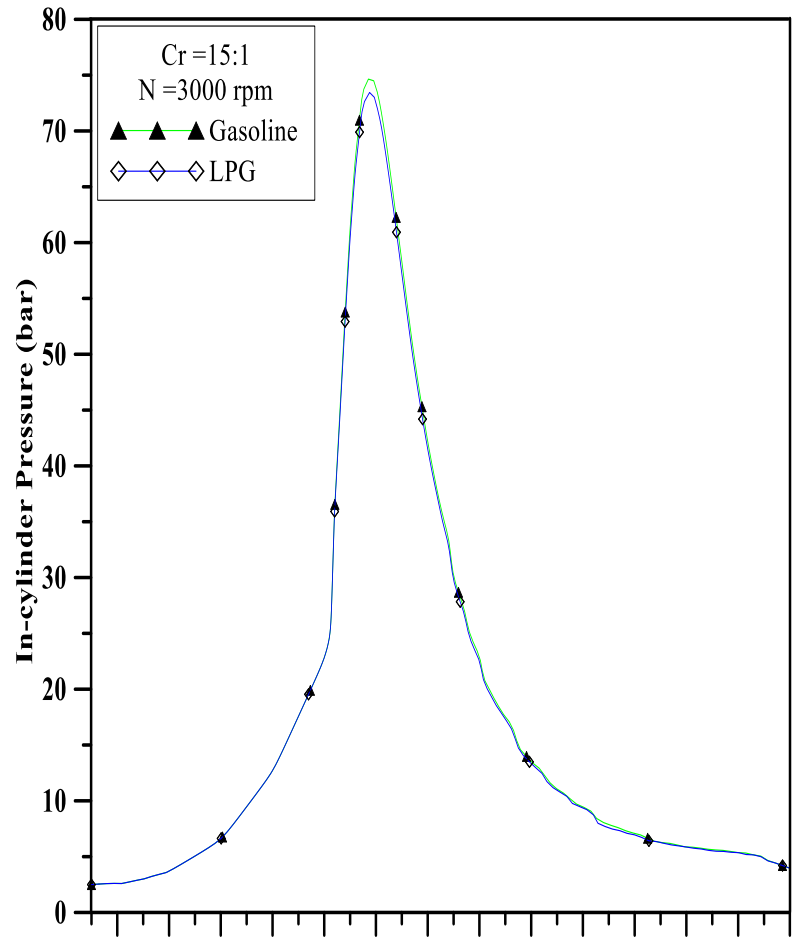

100120140160180200220240260280300320340360 Crank angle (deg.)

(h)

Figure (12): Variation of In-cylinder pressure versus crank angle for brake power equals to $(10 \mathrm{~kW})$. 


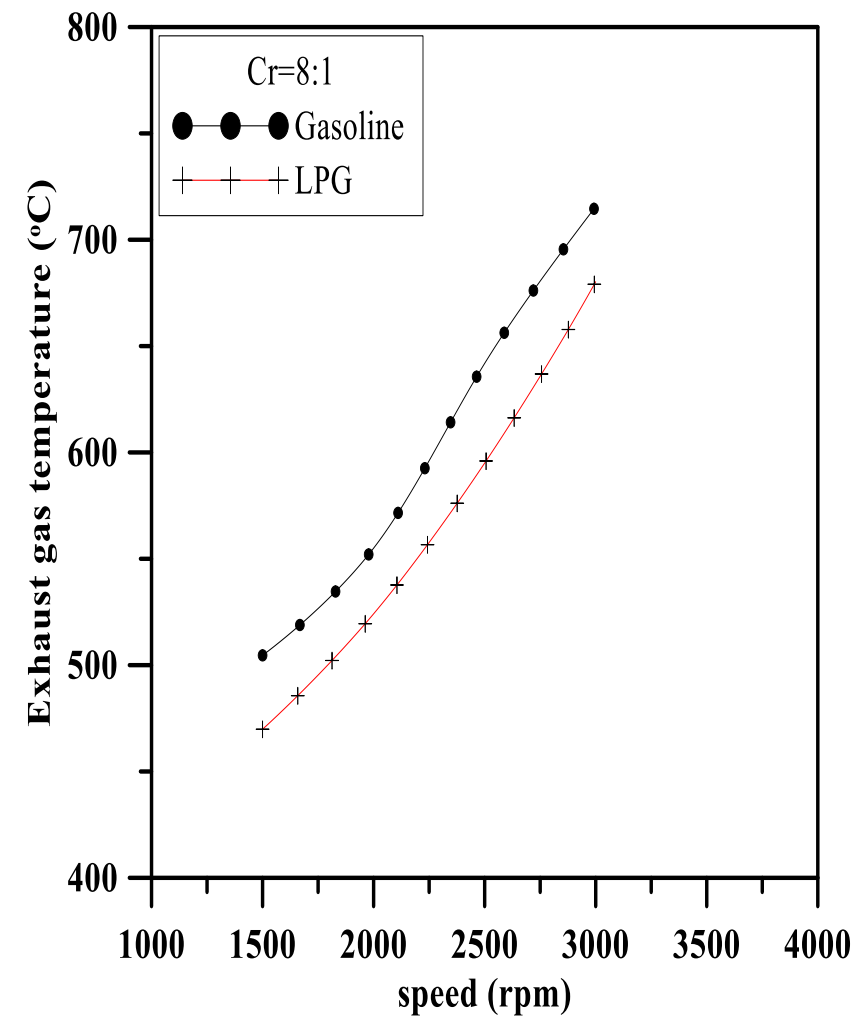

(a)

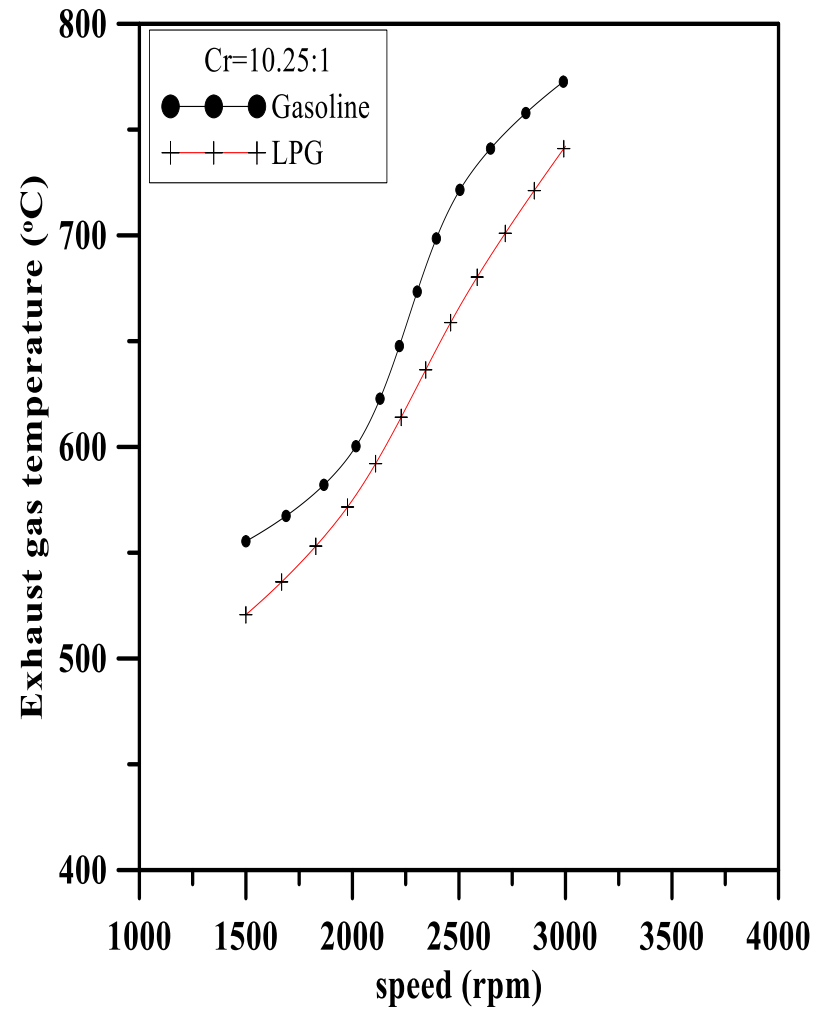

(c)

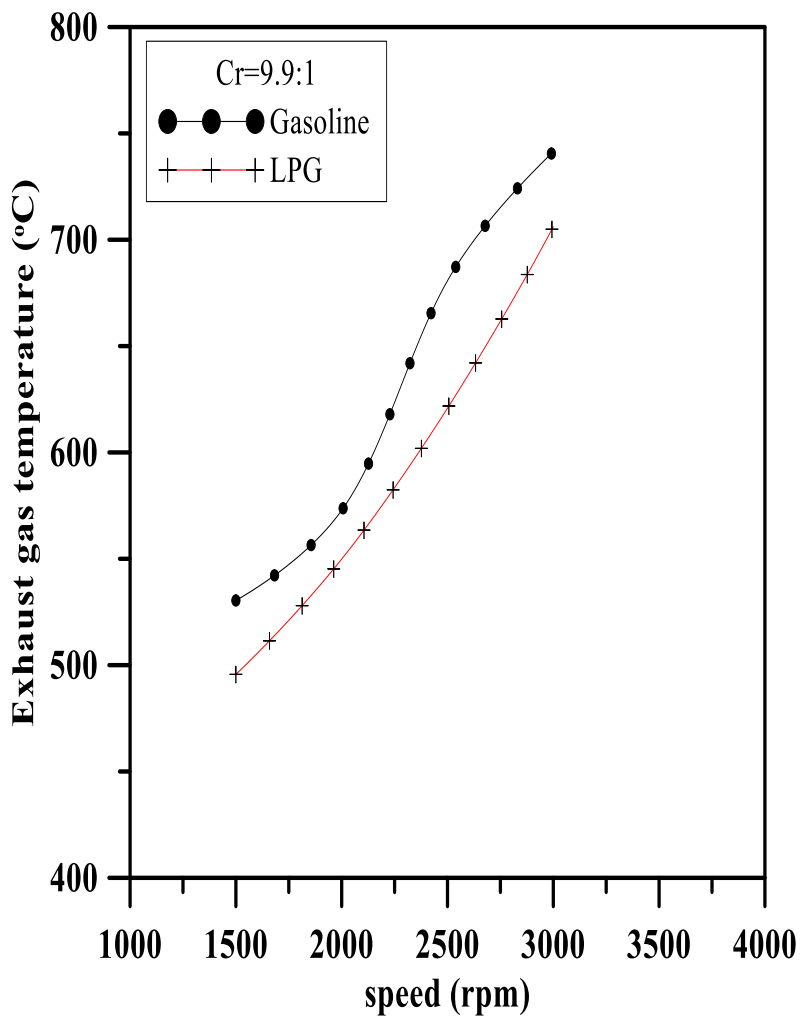

(b)

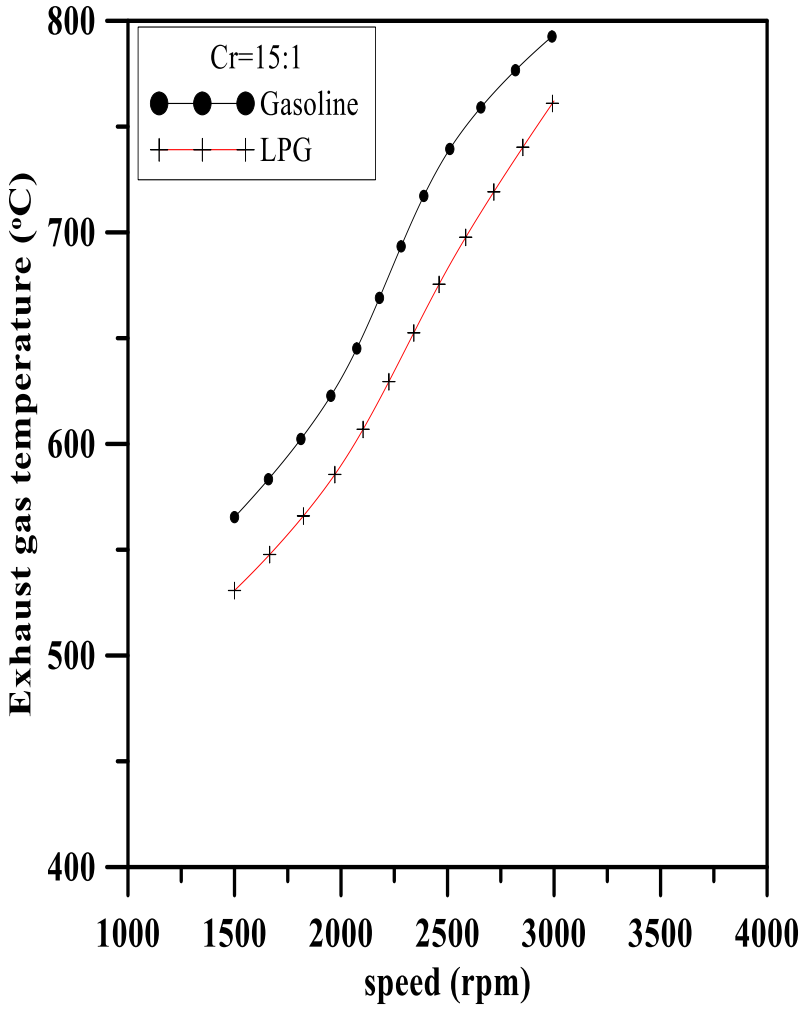

(d)

Figure (13): Variation of exhaust gas temperature versus engine speeds for brake power equals to $(10 \mathrm{~kW})$. 


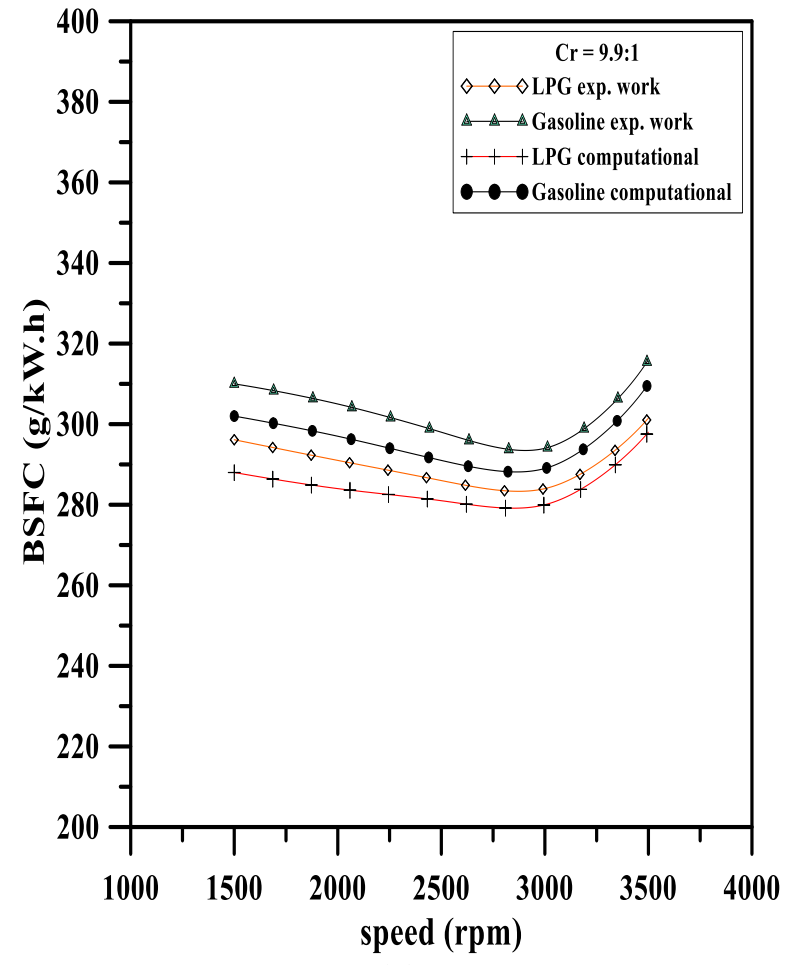

(a)

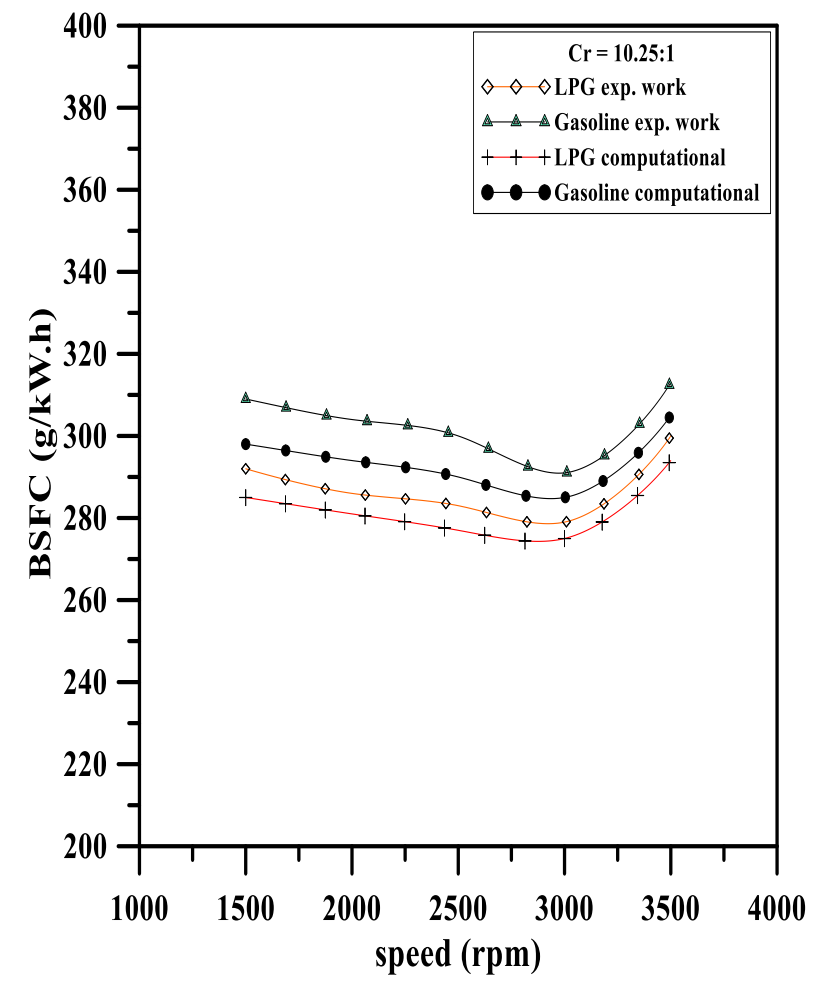

(b)

Figure (14): Variation of brake specific fuel consumption versus engine speed for brake power equals to $(10 \mathrm{~kW})$.

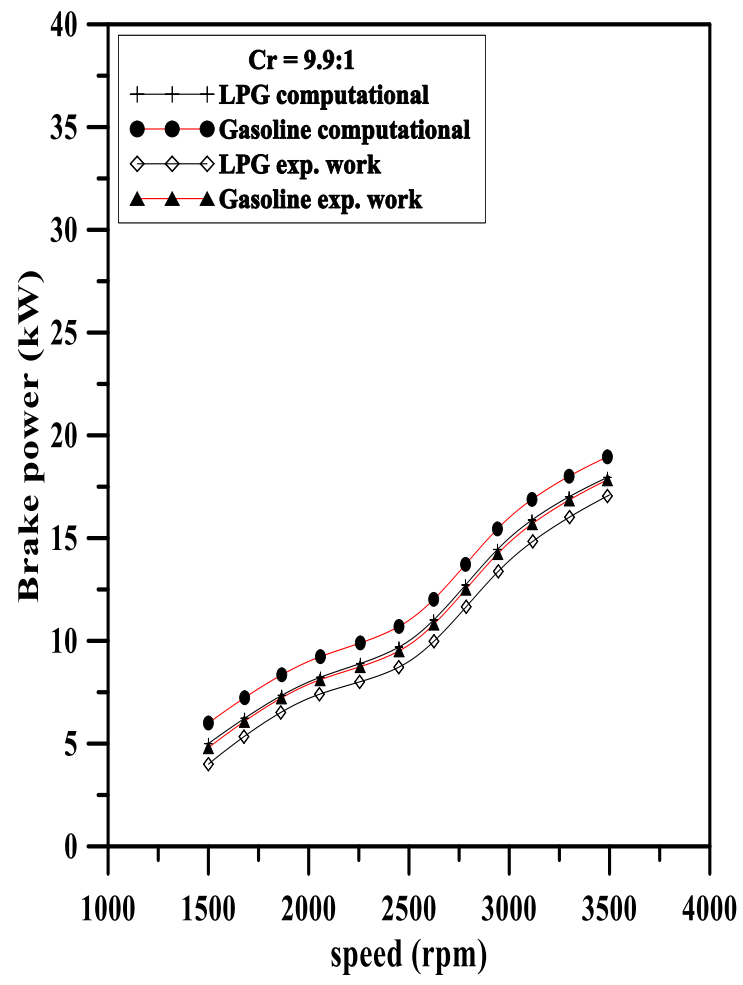

(a)

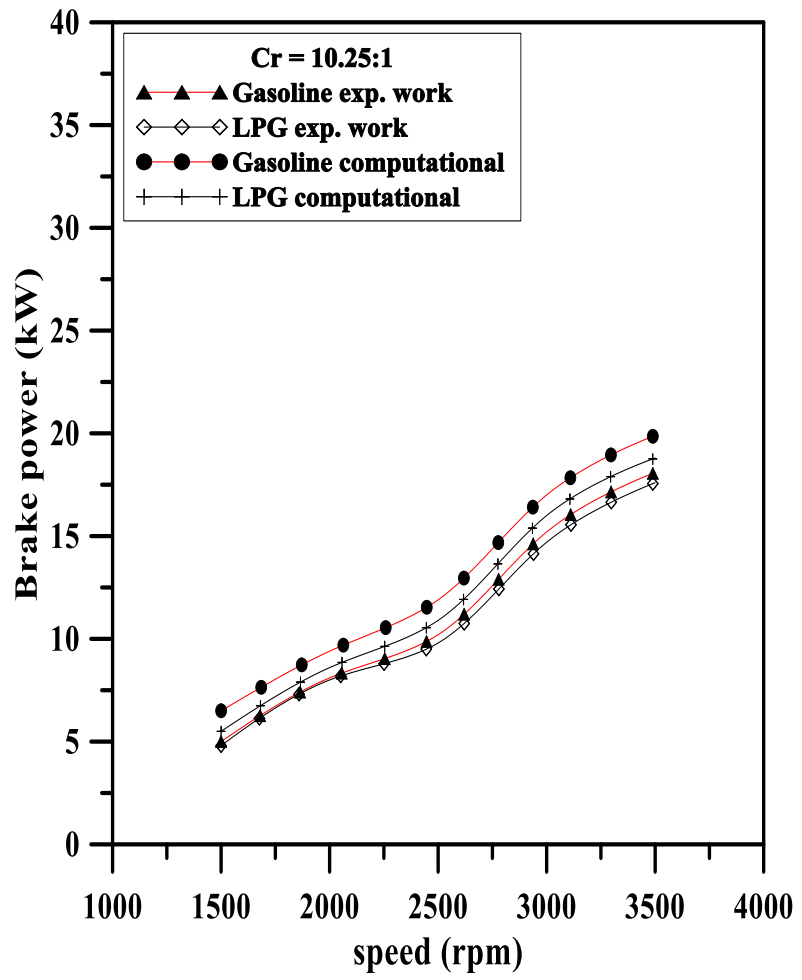

(b)

Figure (15): Variation of brake power versus engine speed. 


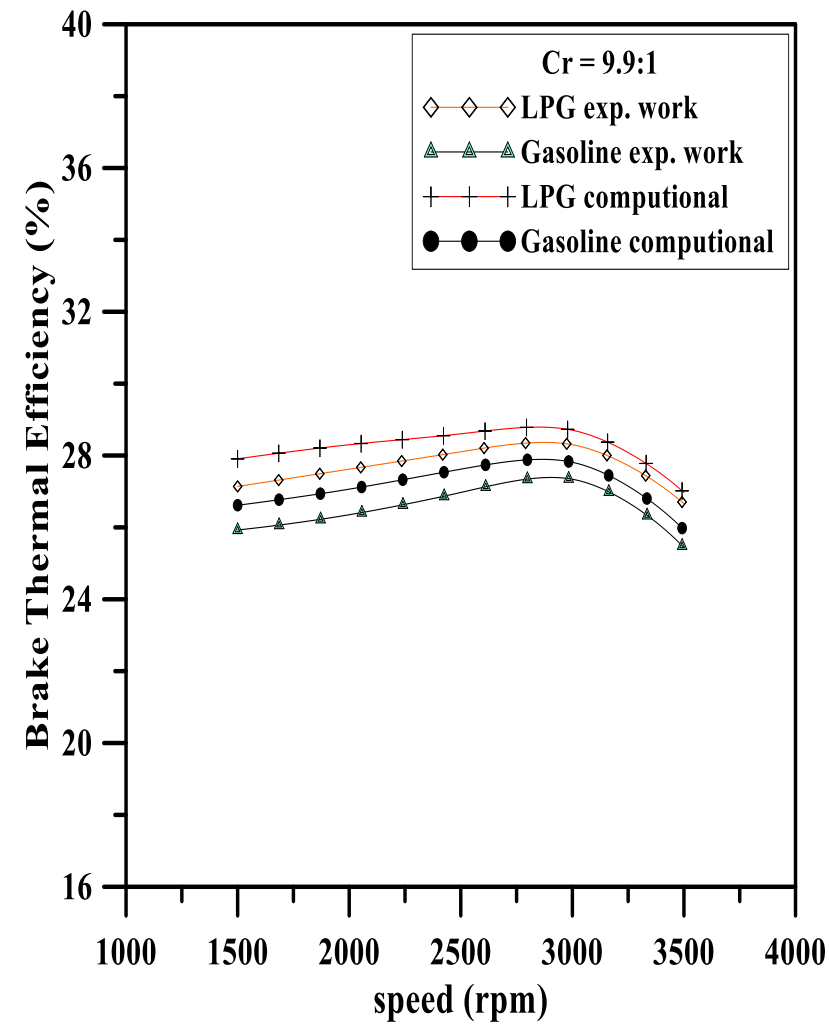

(a)

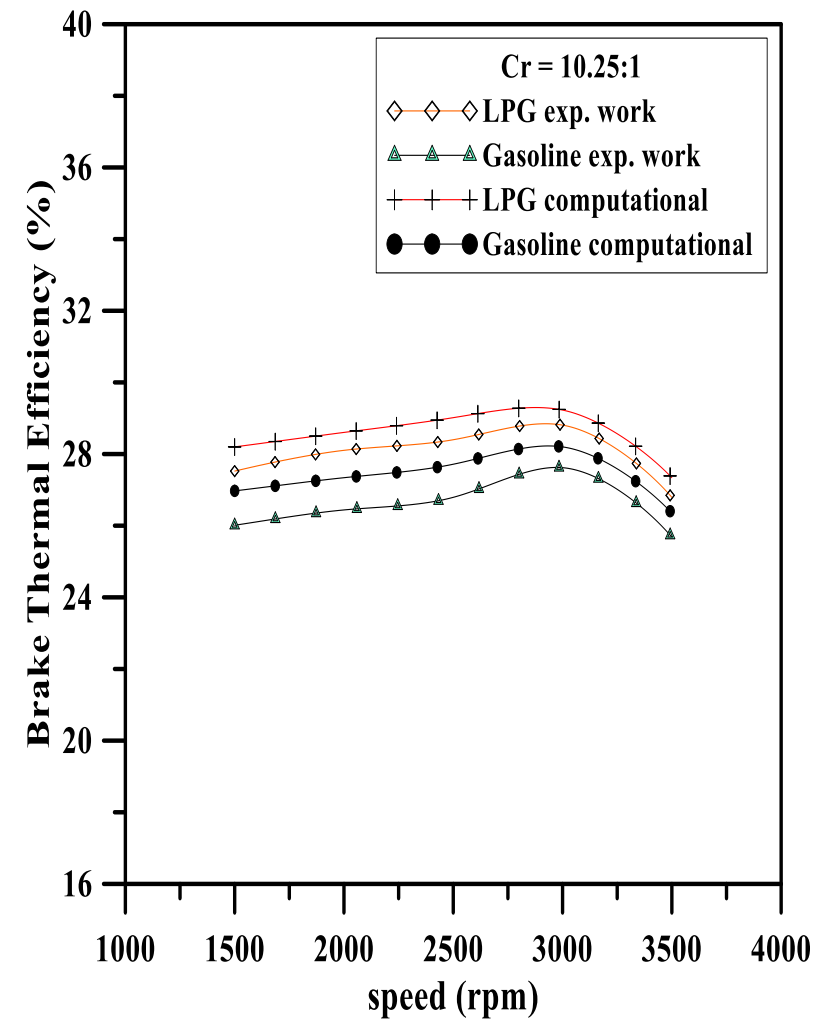

(b)

Figure (16): Variation of brake thermal efficiency versus engine speed for brake power equals to $(10 \mathrm{~kW})$.

\section{REFERENCES}

Arslan O., Kose R., and Ceylan N., Experimental analysis of consumption and exhaust emissions of gasoline and LPG in car engine sunder cold climatic conditions, Energy Sources, Part A: Recovery, Utilization, and Environmental Effects, V.33, pp.244-253, 2010.

Bayraktar H. Theoretical investigation of using ethanol-gasoline blends on SI engine combustion and performance, Ph.D. Thesis, Karadeniz Technical University, Trabzon, Turkey, 1997.

Erkuş B., Sürmen A., and Karamangil M. I., A comparative study of carburetion and injection fuel supply methods in an LPG-fuelled SI engine, Fuel, V.107, pp. 511-517, 2013.

Gumus M., Effects of volumetric efficiency on the performance and emissions characteristics of a dual fueled (gasoline and LPG) spark ignition engine, Fuel Processing Technology, V.92, No.10, pp. 1862-1867, 2011.

Gatea A. M., Amori. K. E., Salih H. U., Experimental assessment of single (petrol) or dual fuel mode (LPG - petrol) for internal combustion engines in Iraq, Journal of Engineering and Applied Sciences, V.14, No.15-16, to get release in July 2019.

Heywood, John B. .Internal Combustion Engine Fundamentals. New York, NY, McGraw-Hill Book Company, 1988. 
Krishna Murthy, N. Madhwesh, B.R. Shrinivasa Rao, Influence of injection timing on the performance of dual fuel compression ignition engine with exhaust gas recirculation, Int .J. Eng. Res. Dev. V.1, pp. 37-42, 2012.

Lata D.B., Misra Ashok, Medhekar S., Investigations on the combustion parameters of a dual fuel diesel engine with hydrogen and LPG as secondary fuels, Int. J. Hydrogen Energy V.36, pp. I3808-I3819, 2011.

Mustafa K. F., and Briggs Gitano H. W., Liquefied petroleum gas (LPG) as an alternative fuel in spark ignition engine: Performance and emission characteristics, International Conference on Energy and Environment, $3^{\text {rd }}, 2009$.

Nirendra N. M., Robert R. R., A Study of the Emissions of a Dual Fuel Engine Operating with Alternative Gaseous Fuels, SAE 2008-01-1394.

Ozcan Hakan and Yamin J. A.A.,"Performance and emission characteristics of LPG powered fourstroke SI engine under variable stroke length and compression ratio" Energy Conversion and Management, V.49, pp. 1193-1201, 2008.

Pearson, R. J., Bassett, M. D., Fleming, N. P., and Rodemann, T., Lotus Engineering software - an approach to model-based design, Lotus Engineering. Hethel, Norfolk, 2002.

Pourkhesalian A. M., Shamekhi A. H. and Salimi F.,Performance and Emission Comparison and Investigation of Alternative Fuels in SI Engines, SAE International, 2009.

Pundkar A. H., Lawankar S.M. and Deshmukh S. " Performance and Emissions of LPG Fueled Internal Combustion Engine: A Review" International Journal of Scientific and Engineering Research, V.3, No. 3, 2012.

ShankarK. S., and Mohanan P., MPFI gasoline engine combustion performance and emission characteristics with LPG injection, International Journal Of Energy And Environment, V.2, No.4, pp. 761-770, 2011.

Snelgrove D.G., Dupont P., and Bonetto R. An investigation into the influence of LPG (Autogas) composition on the exhaust emissions and fuel consumption of 3 bi-fueled Renault vehicles. SAE Paper No. 961170, 1996

Winterbone, D. E., and Pearson, R. J.” Design techniques for engine manifolds: wave action methods for IC engines "Professional Engineering Publications, London. 1999.

Winterbone, D. E., and Pearson, R. J. "Theory of engine manifold design-Wave action methods for IC Engines"Professional Engineering Publications, London. 2000. 